OPEN ACCESS

Edited by:

R. Terry Bowyer,

University of Alaska Fairbanks,

United States

Reviewed by:

Stan Boutin,

University of Alberta, Canada

Matt W. Hayward,

University of Newcastle, Australia

Evelyn Hunter Merrill,

University of Alberta, Canada

*Correspondence: Joel Berger

jberger@wcs.org

Alejandro Vila

avila@wcs.org

Specialty section:

This article was submitted to Behavioral and Evolutionary Ecology,

a section of the journal

Frontiers in Ecology and Evolution

Received: 28 January 2020 Accepted: 20 April 2020

Published: 10 June 2020

Citation:

Berger J, Wangchuk T, Briceño C,

Vila A and Lambert JE (2020)

Disassembled Food Webs and Messy

Projections: Modern Ungulate

Communities in the Face

of Unabating Human Population

Growth. Front. Ecol. Evol. 8:128

doi: 10.3389/fevo.2020.00128

\section{Disassembled Food Webs and Messy Projections: Modern Ungulate Communities in the Face of Unabating Human Population Growth}

\author{
Joel Berger ${ }^{1,2 *}$, Tshewang Wangchuk ${ }^{3,4}$, Cristobal Briceño ${ }^{5}$, Alejandro Vila $^{6 *}$ and \\ Joanna E. Lambert ${ }^{7}$
}

${ }^{1}$ Department FWC-Biology, Colorado State University, Fort Collins, CO, United States, ${ }^{2}$ Wildlife Conservation Society-Global Program, The Bronx, NY, United States, ${ }^{3}$ Bhutan Foundation, Washington, DC, United States, ${ }^{4}$ Bhutan Foundation, Thimphu, Bhutan, ${ }^{5}$ ConserLab, Departamento de Medicina Preventiva Animal, Facultad de Ciencias Veterinarias y Pecuarias, Universidad de Chile, Santiago, Chile, ${ }^{6}$ Wildlife Conservation Society, Chile Program, Punta Arenas, Chile, ${ }^{7}$ Program in Environmental Sciences, Department of Ecology and Evolutionary Biology, University of Colorado Boulder, Boulder, CO, United States

The human population grows inexorably. When Charles Darwin explored the southern cone of South America in 1830, fewer than 1.2 billion people inhabited Earth. When Ehrlich's Population Bomb appeared in 1968, there were $\sim 3.5$ billion people. We approach eight billion today, and biospheric impacts do not abate. We have affected most life forms through climate modification, harvest, erasure and fragmentation of habitat, disease, and the casting of alien species. Given the lack of abatement in human population growth, herein we focus on the modalities of ecological disruptiondirect and indirect-that mitigate the changing role of ungulates in landscapes. Much of what was once generally predictable in terms of pattern and process is no longer. Offshore climatic events have strong onshore consequences, as exemplified by toxic algal blooms in the Patagonian Pacific. These have diminished the harvest of fish and likely resulted in fishermen using dogs to hunt huemul (Hippocamelus bisulcus), the most endangered large terrestrial mammal of the Western Hemisphere. Similarly, human economies foment change in the Himalayan realm and Gobi Desert by increasing the number of cashmere-producing goats, and where dogs that once followed tourists or guarded livestock now hunt a half-dozen threatened, endangered, and rare ungulates, including kiang (Equus kiang), chiru (Pantholops hodgsonii), saiga (Saiga tatarica), and takin (Budorcas taxicolor), spread disease, and displace snow leopards (Panthera uncia). In North America's Great Basin Desert, 100 years of intense livestock grazing created a phase shift by which changed plant communities enabled mule deer (Odocoileus hemionus) colonization. An altered predator-prey system ensued with the arrival of pumas (Puma concolor). Patterns of resilience postulated by Holling (1973) become more difficult to witness in the absence of humans as our domination of 
Earth destabilizes systems beyond return points. These include ungulates both in and out of protected areas. Consequently, only messy projections of future community reorganization seem reasonable, whether related to food webs or assembly rules that once governed ungulate communities of the very recent past.

Keywords: human disturbance, trophic relationships, apex carnivores, mammals, endangered species, predator prey, climate change

\section{INTRODUCTION}

The human population is increasing inexorably. When Charles Darwin explored South America in 1830, fewer than 1.2 billion people inhabited Earth (Goldewijk, 2005). One hundred forty years later, when The Population Bomb (Ehrlich, 1968) appeared, the population was $\sim 3.5$ billion. Now, only 50 years since, we approach eight billion; 30 years hence we will near 10 billion (United Nations Department of Economic and Social Affairs Population Division, 2019), and the biospheric impacts do not abate. Globally, livestock and people constitute $97 \%$ of the world's mammal biomass (Thomas, 2017). We have affected most life forms, restructuring ecological dynamics on six continents not only by climate modification but also by erasing species and fragmenting their habitats and by casting of alien species and disease. So great are the similarities between marine and terrestrial systems that a heuristic contrast using hoofed mammals would reveal that green turtles and whales were the equivalent of bison (Bison bison) or wildebeest (Connochaetes taurinus), yet all suffered reductions in excess of 99\% (Springer et al., 2003; Jackson, 2008; Sanderson et al., 2008).

Ungulates, many of which have regularly played trophic roles through top-down and bottom-up effects, are clearly among those assemblages that have been impacted by anthropogenic pressures (Ripple et al., 2015; Bowyer et al., 2019). Although systems involving these large and small hoofed mammals have operated unhinged from humans, or have only been slightly affected by them/us for millennia, they no longer operate evolutionarily or ecologically as they did across deep time (Vrba and Schaller, 2000). Even ecological baselines that once framed our knowledge of the recent past are often of little modern relevance (Lovejoy and Hannah, 2019). The huemul (Hippocamelus bisulcus), for instance, a cervid that Darwin observed on Patagonia's eastern Atlantic shore and which extended across the Andes to the Pacific, no longer exists across 99\% of their range (Eisenberg and Redford, 1989; Diaz, 1993; Vila et al., 2006). Six of the seven species of wild equids are on the IUCN Red List as endangered.

While the best-studied large protected areas-Yellowstone, Serengeti, and Kruger-offer essential baselines for understanding the recent past in which species had persisted with only slight human impact (Arcese and Sinclair, 1997; Smith et al., 2003), these sites today are but mere postage stamps for the once universal conditions with intact prey and predator assemblages. Although these places no longer have human harvest, the concept of ecological 'stability' was never meant to be a strong hallmark of these protected areas (Sinclair et al., 2010). Today, by definition, we co-exist with rapid biological change. Its pace now and into the future (will) only escalate(s).

Given the lack of abatement in human population growth and the immeasurable impacts, we focus herein on the modalities of disruption-direct and indirect-that mitigate the changing role of ungulates in global ecosystems (Figure 1). We evaluate what is known about various disruptors and how these altered community dynamics and structure the nature of ecological interactions now and likely will in coming decades. Much of what was once generally predictable in terms of pattern and process is no longer, and ecological surprises are regular occurrences (Doak et al., 2008). Consequently, only messy projections of future community reassembly are reasonable. Below, we first illustrate the limitations of our predictive power in interpreting assembly rules in deep time. We then move to extant systems, using the interrelated themes of food webs and assembly, and describe the human-induced extrinsic and intrinsic variables that shape modern ungulate communities and attendant challenges (Figure 1). We close by pointing to lessons of the past and reluctantly suggest that, unless human behavior changes in unprecedented ways, future communities of ungulates will not look much like those of the recent past or even today.

\section{ASSEMBLY AND DISASSEMBLY RULES IN DEEP TIME}

That geological and climatic perturbations create evolutionary opportunity for plants and animals has been well appreciated across parts of three centuries (Darwin, 1859; Wallace, 1876; Simpson, 1944; Webb and Barnosky, 1989). A scrambling of species with vastly different origins not only alters community composition but also leads to extinction and speciation, innovation, and altered niches. Prominent cases involving ungulates include climate-induced "turnover pulses" (sensu Vrba, 1993) of East African antelopes (2.8-2.5 mya) and the ecological reassembly of camelids, suids, cervids, and tapirids that resulted once the Panamanian land bridge re-connected the Americas ( 3 mya) (Webb, 2006). More ephemeral connections farther north involved Beringia, which ultimately enabled the entry of human colonists of Asian descent into the Americas (Webb, 2006). The patterns by which communities assemble or fall apart are often context specific and governed by both type of ecological disruptor and species composition with time as a mitigating factor (Strong et al., 1984; Croll et al., 2005; Woodroffe and Ginsberg, 2005). Yet beyond some generalities of species-area relationships and competition theory, the fuzziness of past rules may be ineffective 


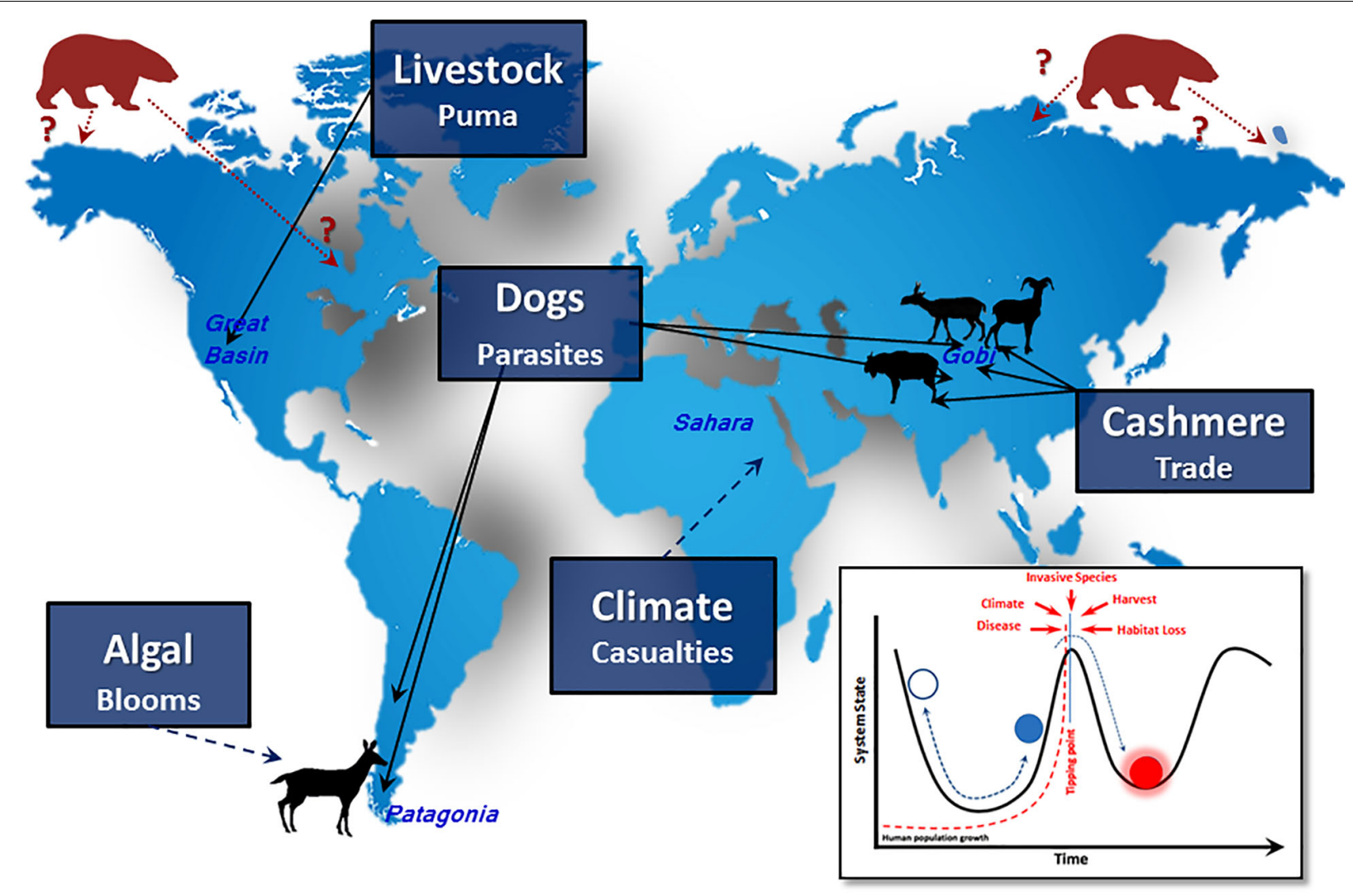

FIGURE 1 | Overview of locations, ungulates, and ecological disruptors. Species silhouettes are pointed out in the text. Inset-modification of Holling's (1986) resiliency model with biotic and climate disruptors coupled with exponential human growth.

predictors of future ungulate communities. The few rules available today for predicting winners and losers in our briskly changing landscapes may not be much other than the admitted oversimplification that generalists tend to out-prosper specialists in human-dominated landscapes (Roemer et al., 2009).

Deeper in time and prior to any human impacts, it is still unclear whether geological events coupled with the loss of species predictably yield to patterned replacement. With 50 million years of mammalian evolution, some ecosystems shared similarities where globally proboscidean-sized species occurred on every continent (Smith and Lyons, 2013; Smith et al., 2015). In other cases, replacement of lost species or colonization of new lands follows varied pathways with uncertain and stochastic representation (Graham and Lundelius, 1984; Strong et al., 1984). Even where the loss or expansion of a species opened or reduced habitat for others, it has not been especially clear which scenario would lead to more species packing or the numerical proliferation of a single dominate one. The African buffalo (Syncerus caffer), for example, collapsed across parts of Africa due to anthrax early in the 20th century while zebra and gazelles flourished (Sinclair et al., 2010), but in North America, why bison became so abundant and whether this occurred at the expense of other species, humans included (Noss, 2012), or may have been predisposed by others is subject to diverse interpretations (MacPhee, 2019). In South America, perhaps it was its long-isolated history with a concomitant reduction in browsing competitors and the loss of equids and proboscideans that enabled the radiation of cervids into some 15 species and into unusual previously unoccupied niches, including huemul (Wemmer, 1987; Geist, 1998; Weber and Gonzalez, 2003; Vila et al., 2006, 2010). The tempo and the mode of past change have guided our understanding of ecosystem structure.

Whatever ecological stability may have once occurred in deeper time is widely challenged today by disturbance dynamics and runaway human population growth (Figure 1). Holling $(1973,1986)$ refocused attention on resiliency and argued it was the magnitude and the variance incumbent within a system that, coupled with disturbance, could shift it to a different state. It is the shape and the scale of modern disruptors and subsequent altered states that complicate projections about stasis and reorganization in future ecosystems that involve not only ungulates but also life support processes.

\section{EXTANT UNGULATES WITH AND WITHOUT PREDATORS}

Despite diversity, visibility, and global geography, much remains unknown about how the world's $\sim 250$ ungulates interact with their environments. Among the array of hoofed mammals are 
specialists and generalists, for which lifestyles and life histories vary based on size, digestive strategies, and vulnerability to predators (Jarman, 1974; Eisenberg, 1981; Barboza and Bowyer, 2000). Variation in body size can be extreme, from the 1to 2-kg Javan mouse deer (Tragulus javanicus) to African elephants (Loxodonta africana) at nearly 7 tons. Regardless of size, ungulates carry the stamp of 'prey' which, by definition, connotes predation. Even adults of species like elephants and rhinos, once considered immune due to their extraordinary size, can become prey (Brain et al., 1999; Loveridge et al., 2006; Power and Compion, 2009), and they certainly defend their young from predators (Cunningham and Berger, 1997). Knowledge of such prey-predator interactions stems from large protected areas where these sorts of dynamics can unfold and be recorded.

The situation differs in most tropical, temperate, and subArctic zones (Geldmann et al., 2014) as the world accentuates its transformation (Redford, 1992; Lovejoy and Hannah, 2019). Nearly $80 \%$ of the world's carnivores $15 \mathrm{~kg}$ or larger are in decline (Ripple et al., 2014; Bauer et al., 2015), and predation on larger ungulates has been relaxed or lost as a selective force. The world's largest felids, tigers and lions, are absent from $\sim 95 \%$ of their modern historic ranges (Walston et al., 2010), and wolves (Canis lupus) and grizzly bears (Ursus arctos) are gone from 85 to $100 \%$ of their respective North American desert and shrub biomes (Laliberte and Ripple, 2004). Although some carnivores may regulate ungulate populations under specific conditions (Sinclair et al., 2003; Bowyer et al., 2005), a complex interplay among many competing factors also operate (Sinclair et al., 2010; Pierce et al., 2012; Smith and Ferguson, 2012; Bowyer et al., 2014). Nevertheless, the history of large herbivore overabundance as a consequence of predator removal is a rich one (Leopold, 1949; Serrouya et al., 2011; Krausman and Bleich, 2013), with frequent suggestions that replacement by human hunting is functionally redundant-but this is not the case due to both direct and indirect effects (Berger, 2005). The notion that prey-predator dynamics have been strongly altered is not contestable nor is that change has consequence for understanding current and future trophic dynamics (Terborgh and Estes, 2010; Estes et al., 2012; Bonacic et al., 2019).

\section{Super Abundant Herbivores}

In the recent past, mostly within the last century or so, saiga (Saiga tatarica), white-tailed gazelles (Gazella subgutturosa), and perhaps guanacos (Lama guanicoe) exceeded one million individuals in Kazakhstan, Mongolia, and Patagonia (MilnerGulland et al., 2001; Novaro et al., 2004; Novaro and Walker, 2005; Olson et al., 2005). The East and Southern African grasslands shared in uncountable numbers of wildebeest and springbok (Antidorcas marsupialis), and as recently as the 1980s, African elephants exceeded one million (Wittemyer et al., 2014). Such population numbers may arise due to migratory behavior where predation is avoided (Fryxell et al., 1988).

Among other super abundant large mammals were the North American bison, variously estimated at 10-30 million (Berger and Cunningham, 1994); their large populations may be associated with the colonization of a relatively young grassland system in the early Holocene (Geist, 1978; Stebbins, 1981; Sanderson et al., 2008). Whatever the multiple routes to numerical domination, it is unlikely that predation controlled their numbers or that of caribou, although some $80 \%$ plus of Arctic caribou (Rangifer tarandus) populations are in decline (Vors and Boyce, 2009). A few optimistic spots have emerged with saiga and guanacos rebounding (see below). While super abundant populations of some species occur today, these tend to be beneficiaries of habitat change like white-deer (Odocoileus virginianus) and feral species such as pigs (Sus scrofa) and horses (Equus caballus). The conditions of the past will not be those of the future.

\section{Altered and Unaltered States of Ungulates}

The default condition for most of earth's living history has been one of predator and/or parasite and prey accompanied by periods of slow and rapid change (Vermeij, 1993). Variations occur and lead to evolutionary innovation. Prior to massive human-induced habitat alterations, Wallace (1876) wondered about causes of differences among Malayan archipelago faunas and why different arrays of carnivores and ungulates assembled. Indeed some northern islands like Svalbard, those close to the Norwegian and Alaskan coastlines, and even those in Lake Superior have had moose (Alces alces) or caribou in the absence of large carnivores (Peterson, 2007; White et al., 2014). The native wild reindeer of Svalbard, for instance-following a pattern of dwarfism on islands-are small, about the size of pronghorn (Antilocapra americana), and fat and have only polar bears (Ursus maritimus) to flee (Tyler et al., 2008). While polar bear numbers increase on land due to reductions of sea ice, the overarching effects at the terrestrial food level (Rode et al., 2015a,b), especially as predators of ungulates, are not clear (Figure 1), although instances of predation on Arctic ungulates exist (Derocher et al., 2000; Berger, 2018).

With the advent of human weaponry and poisons, however, much of these past putatively non-human-influenced distributions of ungulates and carnivores are now intensely modified. All large carnivores suffer range reductions (Ripple et al., 2014; Wolf and Ripple, 2017), some so massively that these ungulates no longer face predators (Caro, 2005), a deviation from the default state of functional relationships (Soulé et al., 2003) which is achieved only by maintaining carnivores or restoring them (Pyare and Berger, 2003; Berger, 2007b). Wolves, for instance, were reintroduced back into Yellowstone after nearly 60 years of absence (Smith and Ferguson, 2012) and currently number $\sim 1,500$ in the western United States; wolves are also now recovering in Scandinavia, France, Italy, Germany, and Eastern Europe (Boitani and Linnell, 2015). Also rebounding are cougars (Puma concolor) in the United States, expanding into Canada's Yukon and, at the hemisphere's other extreme, recolonizing parts of Patagonia where they had been previously extirpated (Walker and Novaro, 2010). Both wolves and pumas excise strong impacts on prey populations, sometimes because individuals learn to specialize and this behavior can reduce a population's growth rate for more than a generation (Festa-Bianchet et al., 2006), so can weather including North Pacific Oscillations, El Niño, and 
other off-shore currents (Hebblewhite, 2005; Post et al., 2009, 2013; Loe et al., 2016).

\section{Ungulates and Recognition of Native Carnivores}

Beyond climate, short-term weather events, and large carnivores, prey must have regularly dealt with altered predation regimes and (re-)colonizing native predators (as opposed to alien ones) (Blumstein and Daniel, 2005), but predation regimes change, and common examples involve coyotes (Canis latrans), which colonized the east coast of the United States, and golden jackals (Canis aureus), now moving into southern Europe (Ćirović et al., 2015; Trouwborst et al., 2015). Similarly, the colonization of the Great Basin a century ago brought cougars into a system where they had not occurred (see below), yet little was known about the potential sensitivity of prey to a novel carnivore as the dynamics of ecological systems shift.

A relaxation or cessation in predation due to humancaused extirpation of effective carnivores has consequences including diminished recognition of predation risk to putatively 'novel' carnivores (Berger et al., 2001b; Carthey and Blumstein, 2018). Field experiments and observations, however, reveal both curiosity and trepidation when exposed to carnivores (Figure 2), and those sensory modalities of predator recognition return once re-exposure happens (Berger, 2007a, 2008a). Conversely, demographic effects will proliferate as habitat is altered, carnivore ranges shift, and when prey lack appropriate or effective defense responses.

\section{Meso-Predators and Ungulates}

The persistence, loss, or return of large native carnivores has notable direct and indirect effects on ungulates via mesopredators. The interactions and the outcomes between differentsized carnivores and potential prey species in the Greater Yellowstone region of Wyoming are illustrative (Figure 3). During periods that persisted until the early and mid-19th century, including the present-day Yellowstone National Park (YNP; formally created in 1872), there were seven native ungulates including bison, pronghorn, and elk; four carnivores at $40 \mathrm{~kg}$ or more also existed-grizzly bears, black bears (Ursus americanus), cougars, and wolves. Elk, bison, and mule deer (O. hemionus) currently comprise important components of wolf diet, and both species of bears prey on neonate elk (Metz et al., 2012; Middleton et al., 2013). Wolves were extirpated in YNP and in adjacent Grand Teton National Park to the south; they were re-introduced into YNP in 1995 and re-colonized Grand Teton late in 1997. The 21st century fauna of YNP and adjacent Grand Teton now is probably much like what it was prior to modern weapons (Figure 3), although species abundances have certainly changed as hunting and other forces outside and within parks excise prominent effects (Smith et al., 2003, 2004). Fencing and habitat conversions, for instance, have blocked migration routes beyond parks (Berger et al., 2006), whereas the establishment of food stations to subsidize elk at 23 winter feed grounds through the Greater Yellowstone Ecosystem inflates their population sizes (Smith et al., 2004). That elk are key components of wolf diet
(Figure 3) or that their high densities coupled with protection facilitate local coyote population sizes within the parks is not a leap of faith.

The inverse relationship between coyote and wolf density (Berger and Gese, 2007) suggests that coyote predation on pronghorn fawns is highest when protected and wolf densities are low-which is the case in protected areas like Grand Teton (Figure 3) where annual juvenile mortality approaches 90\%; beyond park boundaries, it is less intense than in wolfoccupied areas (Berger et al., 2008). Similar patterns of fawn mortality occur in YNP (Barnowe-Meyer et al., 2009), where migration beyond the park no longer occurs (Berger et al., 2006). A complicating factor in understanding meso-predator release (Prugh et al., 2009) is that bottom-up forces also mediate prey availability, especially rodents and hares, the availability of which should affect predation rates in generalist carnivores like coyotes (Cypher and Spencer, 1998; Garrott et al., 2007).

In both Grand Teton and Yellowstone national parks, whitetailed jack rabbits (Lepus townsendii) are gone from the former and much reduced in the latter, a situation that has changed from when the parks were established (Berger, 2008b). Elsewhere hares are key dietary elements of coyotes, as once they were in the Teton region; when hares are of low density, predation on domestic animals may increase (Stoddart et al., 2001). Consequently, in both parks, it is uncertain whether high predation rates on pronghorn fawns are a consequence of the loss of alternative prey (hares) or if these arise because high ungulate densities reduce fawn hiding cover and therefore increase their vulnerability (Berger, 2008b). Regardless of the process-prey switching, apparent competition (see below), or something else, ecological dynamics within even protected areas have changed as a consequence of human management beyond boundaries.

As a global phenomenon, meso-predator release can impact ungulates (Brashares et al., 2010). Where grizzly bears have been lost or reduced, black bears subdue growth in moose populations through reduced recruitment of young (Schwartz and Franzmann, 1991); for elk, calf mortality can approach 50\% (Zager and Beecham, 2006). In western Africa, where lions (Panthera leo) and leopards (Panthera pardus) have been extirpated, baboons (Papio cynocephalus) assume a mesopredator role and kill the young of different ungulates (Brashares et al., 2010). Elsewhere leopards apparently adopt a similar niche as their feasting on ungulates changes in the presence of tigers (Panthera tigris) (Harihar et al., 2011; Athreya et al., 2013). More broadly, only recently has data been accumulating on how meso-predator release alters predation on ungulate neonates or adults (Roemer et al., 2009; Grovenburg et al., 2011; Benson and Patterson, 2013; Quintana et al., 2016). Information also accumulates on how the loss or the retention of carnivores affects prey spacing, distribution, and movement (Ripple et al., 2014).

\section{Buffer Zones and Unintended Vulnerability}

In 1910, the Scottish-born naturalist John Muir traveled to Africa and suggested that human entry into the system mediated a complex three-way interaction among prey, predator, and people: 

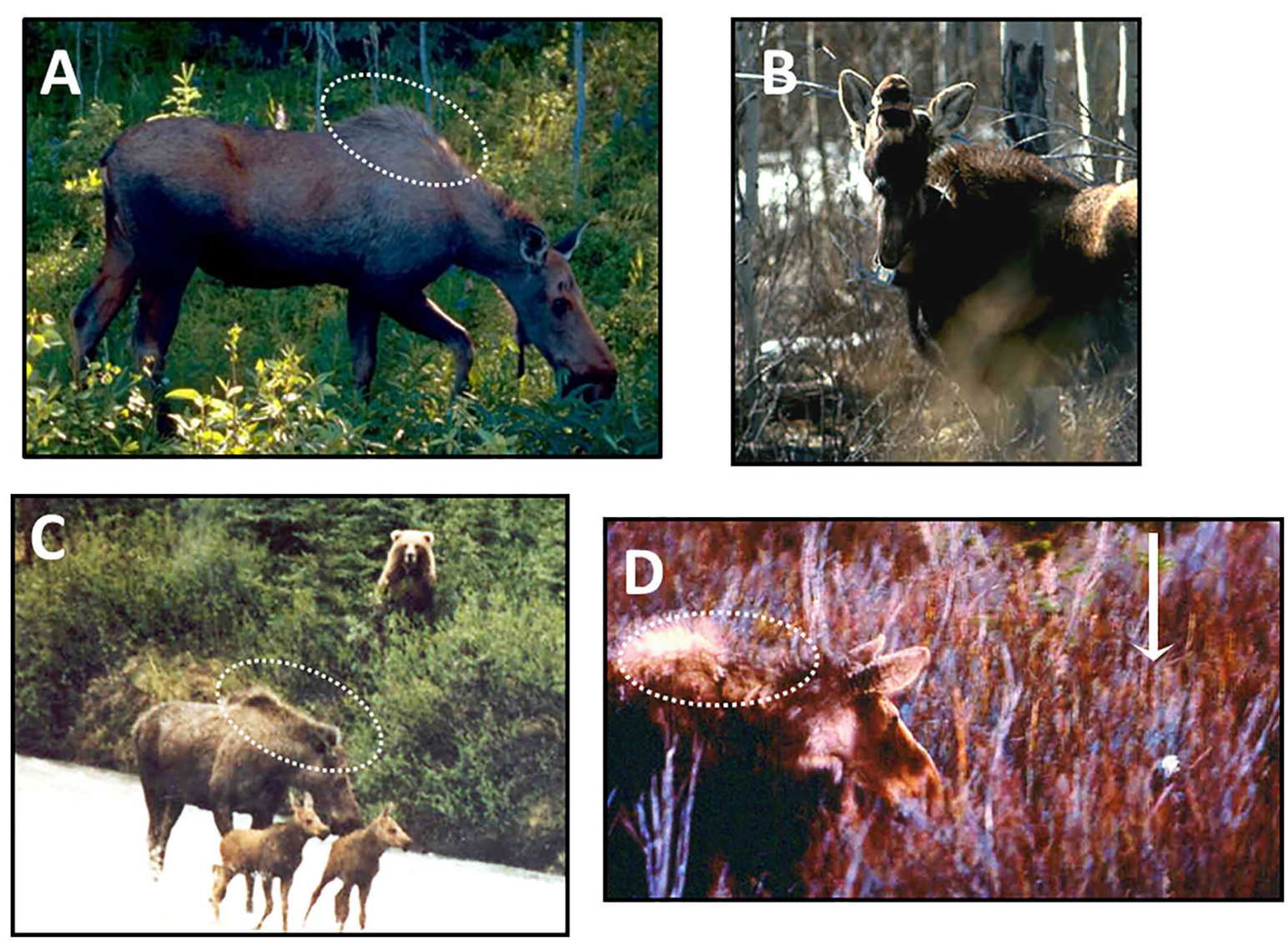

FIGURE 2 | Typical response of moose when exposed to a familiar predator and its cues. (A) Moose with little obvious concerns of eternal threat. (B) Olfactory response to exposure of wolf urine delivered by a projectile. (C) Pilo-erection and retraction of ears during interaction with a grizzly bear. (D) Pilo-erection but no ear retraction in a naïve moose with no prior exposure to grizzly bear feces (wrapped in porous tissue).

'Most of the animals seen today were on the Athi Plains (Kenya) and have learned that the nearer the railroad the safer they are from the attack of either men or lions.' He watched zebras and giraffe (Berger, 2007b). In the intervening 110 years, we have created deliberate and inadvertent refuges to favor and diminish bio-complexity to the point where even large protected areas may not do justice to represent ecological baselines (Arcese and Sinclair, 1997). Purposeful enhancements include habitat improvements through re-creation of fire regimes and removal of exotics (Dayer et al., 2019). More subtle factors alter predation regimes including: (1) humans as an indirect shield and (2) 'apparent competition,' which is the facilitation of a single species that changes the dynamics of another species where both are prey for a single predator (DeCesare et al., 2010). In these cases, as elaborated below, our presence and infrastructure have inadvertently altered species distributions, changed behavior, and re-structured prey-predator interactions.

\section{Human Shields}

The Human Shield Hypothesis (HSH) predicts that prey species will redistribute themselves in the absence of predation, and a commensurate shift will occur by co-association with humans and/or concomitant infrastructure, a behavior that increases avoidance of predators (Berger, 2007b; Sarmento and Berger, 2017). While it is obvious that species change occurs in consort with the degree of human threat and reward (e.g., crop raiding in elephants and elk), as protected areas are progressively fragmented into smaller pieces of disturbed landscapes, encounters with humans will only increase. In the United States, with some 420 national park units and an annual visitation of 300 million plus (Beissinger et al., 2017), only a few remote parks of large size enable functional predator-prey relations (Berger, 2017). In the lower United States, the bulk of visitation occurs, and an inevitable consequence of traffic, people, and hikers is habituation which, in turn, may shape prey vulnerabilities to predators (Geffroy et al., 2015).

Predictions of $\mathrm{HSH}$ have been confirmed for numerous ungulates and other mammals-Axis deer (Axis axis) and wildebeest avoid tigers and lions by using lawns in and around tourist lodges; the mountain nyala (Tragelaphus buxtoni) narrows down distance to humans to enhance protection from predation (Atickem et al., 2014), and vervet monkeys (Chlorocebus pygerythrus) avoid leopards by associating with researchers (Isbell, 1990). A more detailed project that spanned a decade revealed that moose used human infrastructure to avoid predation on neonates in the southern Greater Yellowstone 


\section{Initial Conditions \\ 1850-1900

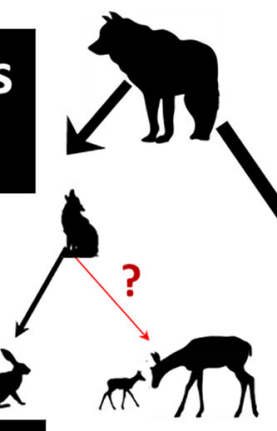 \\ Apex Carnivore \\ Wolf \\ Meso-Predator \\ Coyote

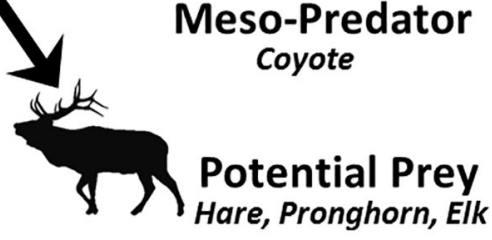 \\ Current Status}

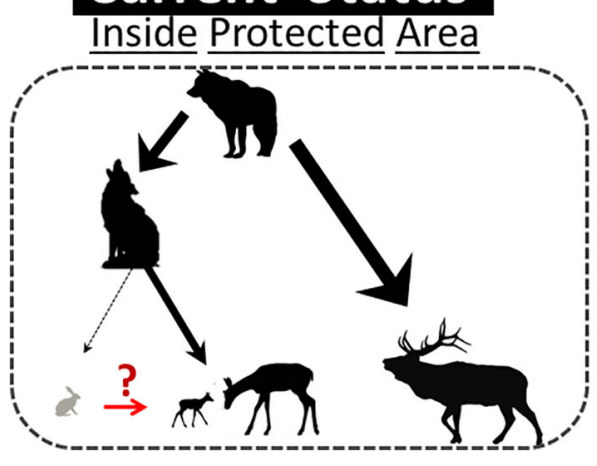

Beyond Protected Area

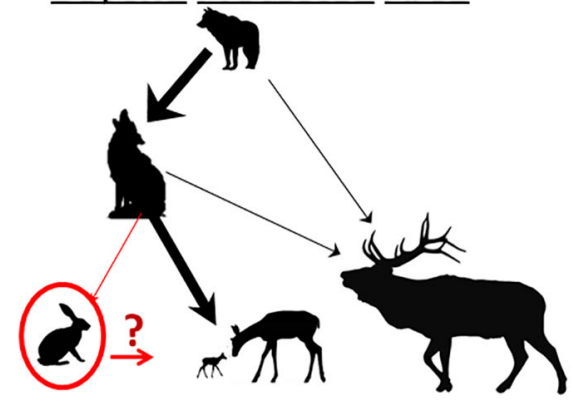

FIGURE 3 | Schematic of temporal change in a prey-predator food web in a protected area of the Greater Yellowstone Ecosystem (Wyoming) spanning about 150 years. The top illustration reflects wolf, coyote, elk, pronghorn, and white-tailed jackrabbits. The arrow width reflects the strength of predation intensity. The relative size of the icons depicts a positive or a negative relationship, and the red notation reflects uncertainty.

Ecosystem (Figure 4). Of two classes of adult females-pregnant and non-pregnant-in areas (i) generally lacking grizzly bears and (ii) with their increasing numbers, only pregnant females moved progressively closer to paved roads to give birth. There were no such movements by either non-pregnant females or females with calves where bears were lacking (Figure 4). Although grizzly bears can account for more than $75 \%$ of the mortality on neonates elsewhere, they tend to be road-averse until strongly habituated (Berger, 2007b, 2008a). Human shields have been reported from other protected areas where high human visitation dampens antipredator responses including vigilance, grouping patterns, and/or the use of traditional refuge habitats for predator avoidance (Caro, 2005; Sarmento and Berger, 2017). Such phenomenon may be more prevalent in national parks than beyond protected boundaries since animals habituate to well-behaved people, and this sort of behavior can then result in increasing ungulate density to the point that heavy browsing affects other components of biological diversity (Hebblewhite et al., 2005).

\section{Apparent Competition}

Buffering against predation also occurs, typically as an indirect consequence when one prey species becomes either more or less abundant, a scenario that then alters predation pressure. By definition, apparent competition involves a decrement in the population growth rate of one of the species (DeCesare et al., 2010). Such patterns become of increasing concern because they frequently arise due to unintentional but broad humanmediated disturbances of natural systems. Forestry practices, roads and energy infrastructure, and habitat succession exemplify such perturbations, although others exist and involve native or alien species, sometimes both simultaneously. An example of this derives from the aforementioned case involving hares, coyotes, and pronghorn, in which the availability of hares as prey may have been affected by excessive grazing practices (Berger, 2008b). A potential consequence is that the loss of hares renders an increase in coyote predation on fawns (Figure 3 ). In a related fashion, the initiation of wolf control in parts of Alaska has possibly played a role in the inverse relationship between snowshoe hare (Lepus americanus) abundance and Dall sheep (Ovis dalli) lamb survival as mediated by coyotes (Arthur and Prugh, 2010).

Under apparent competition, both native and introduced species seem to respond comparably. Bighorn sheep (Ovis canadensis), for example, in the western Great Basin Desert and in New Mexico, often decline when mountain lions shift from mule deer as prey to native sheep in the absence of predator removal (Gibson, 2006; Rominger, 2018). Landscapelevel disturbances such as fire and logging alter forest structure in western Canada. As moose densities increased in response, so did those of wolves; however, predation-related effects were strongest on woodland caribou whose population declined (DeCesare et al., 2010). Similar but inadvertent subsidies of one prey species by another are widespread, involving similar patterns for domestic, feral, and free-roaming alien species. In Patagonia, guanacos, the most abundant native ungulate, are shielded because domestic sheep (Ovis aries) (Baldi et al., 2004), European hare (Lepus 


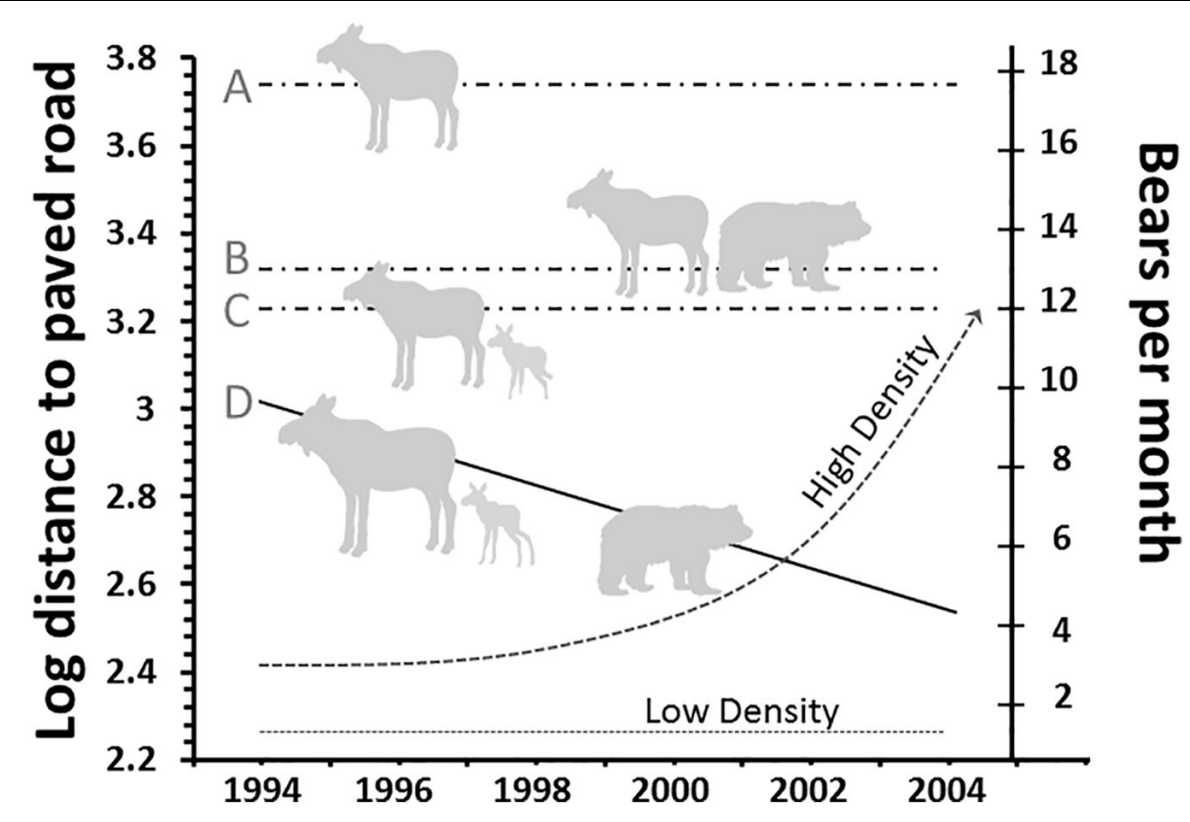

FIGURE 4 | Mean distance $\left(10^{2} \mathrm{~m}\right)$ of female moose of different reproductive status to roads during the spring parturition season. Non-pregnant females (A) in areas lacking and (B) with grizzly bears on days of median birth for conspecifics and for birthdates where bears were lacking (C) and present (D). Modified from Berger (2008a).

europaeus), and red deer (C. elaphus) are the predominant prey of the native carnivore community which includes pumas (Novaro and Walker, 2005). A last example involves the endangered Przewalski's horses (Equus przewalskii) which were re-introduced into the relatively small $\left(\sim 500 \mathrm{~km}^{2}\right)$ unfenced Hustai Nuruu National Park in Mongolia. Hundreds of domestic horses and livestock graze outside the protected boundaries. Although red deer colonized the park, their densities are low and wolf diet consists mostly of domestics, but foal recruitment in Przewalski horses is low because of wolf predation. A management objective is to increase the red deer numbers to buffer as alternative prey (Van Duyne et al., 2009).

The above scenarios represent just a few templates that characterize the altered states of ungulate populations and community interactions. Both the concept of human shields and the conditions by which one or more species of prey alter the demography of others emanate from initial perturbations to the system. Change is unavoidable as human populations enter into formerly non-anthropogenic landscapes. Now and far into the future, ever-increasing numbers of tourists will visit protected areas with unpredictable outcomes. Vegetation dynamicsespecially bottom-up-will govern ungulate community structures and affect species abundance, degree of food overlap, and population dynamics with secondary and tertiary impacts at different trophic levels (below).

\section{Plant-Herbivore-Mediated Tri-Tropic Interactions}

Dominant species alter vegetation (Koerner and 72 members of the Grazing Exclosure Consortium, 2018). Large body size and super abundance are two, not necessarily twin, traits that affect herbivory. In particular, whereas some past continental ecosystems had especially large numbers of African elephants and North American bison, the effects can still be approximated and continue to play out at local scales (Bond, 2008; Hess et al., 2014; Moran, 2014). Elephants have been responsible for the conversion of forest and woodlands to grasslands and savanna (Owen-Smith, 1988; Sinclair et al., 2010), although precipitation, fire, soils, and ungulate density mitigate influences (Augustine and McNaughton, 2006; Pringle et al., 2007; Bond, 2008), and although in not all cases, elephant abundance does affect biodiversity. In miombo woodlands, increasing densities had little apparent effect on bat communities (Fenton et al., 1998). The impacts of other large-bodied grazers whose numbers are not controlled by predators or freed from constraints due to disease or interspecific competition (Sinclair et al., 2010) do exert a strong control of plant communities with coincident spillover effects on birds and insects (Sharam et al., 2009). Herbivory resulting from species as different in size as dik diks (Madoqua kirkii) and elephants have also changed the habitat use and behavior of rodents and small carnivores (Long et al., 2017) with top-down forces interacting with bottom-up ones (Louthan et al., 2019).

Most of the world's ungulates are heavily impacted by management and capably affect vegetation and other elements of biodiversity (Davidson et al., 2012; Ripple et al., 2015). For at least a million years, the hominin lineage has been associated with big game hunting; the evidence for our ancestral top-down impacts on prey species is clear in some instances, although not in others (Grayson et al., 2001; Barnosky et al., 2004).

In modern times, our trophic impacts have been modified both through direct and indirect actions. In North America, white-tailed deer have variously been estimated at up to 30 
million individuals (Rooney, 2009). In eastern deciduous forests, the effects of deer are mediated through heavy browsing (Goetsch et al., 2011) and include the suppression of sapling recruitment, diminishment of shrub-nesting birds and insectpollinated plants, and reduced caterpillars (McShea et al., 1997; McShea and Rappole, 2000; Wheatall et al., 2013). Beyond these effects, deer introduced to Anticosti Island inevitably caused the local extinction of black bear (Cote et al., 2004; Cote, 2005). The homogenization of temperate forests through excessive browsing coupled with the absence of predation has long-term consequences, suggesting a tipping point and phase shift into future grasslands (Rooney and Waller, 2003; Rooney, 2009; Ripple et al., 2019). Far to the west, mule deer, elk, and moose have secondary and tertiary effects on water nutrients, aquatic species, and amphibians depending on predation regimes (Bowyer et al., 1997; Kie et al., 2002; Ripple and Beschta, 2006). Moose, for example, where hunted, structured greater neoptropical migrant diversity through reduced browsing on willows, but in Grand Teton National Park-where protected and grizzly bears and wolves were once extirpated-several species did not occur due to excessive browsing, which resulted in habitat simplicity (Berger et al., 2001a). Elk, despite their more catholic feeding niches, also show great propensity to alter plant species diversity as well as shape bird and butterfly communities under inflated densities (Neff et al., 2007; Stewart et al., 2009; Ripple et al., 2019).

The above accounts concentrate on contemporary systems mostly without co-evolved predators and attendant effects on biodiversity beyond vegetation. Some attention has focused on past Holocene community constitution (Vrba, 1993; Ripple and Van Valkenburgh, 2010), including disarticulation and now modern reconstitution as modulated by climatic change (see below), but some 10 millennia after ungulate domestication (Clutton-Brock, 2012), a genesis that initially moved forth slowly by humans in their pursuit of bettering livelihoods now engulfs all continents (Bonacic et al., 2019). The playing fields of the past and the present are not the ones to be expected of the future despite gains in ungulate and carnivore reintroductions that re-establish varying levels of tri-trophic interaction.

\section{DISASSEMBLY AND REASSEMBLY WHERE HUMAN ECONOMY AND CLIMATE INTERSECT}

\section{The Deserts-Africa, North America, and Asia}

Ecological change across deep and short time is well appreciated. Hoofed mammals colonized new habitats during interglacial periods, when continental land bridges opened and closed, and species ranges expanded or contracted (Geist, 1978; Eisenberg, 1981; Webb, 2006). Some species adapt to changes; others fail to. A quickened pace occurs, however, as pastoralists alter the biomass of native herbivores by transforming systems in unprecedented ways which in the past (and continues today) included a profusion of alien species of domestic origin. North
Africa exemplifies the first climate-driven alteration in an era with contemporary humans but lacking our current humaninduced $\mathrm{CO}_{2}$ climate-prompted footprint.

\section{The Sahara-Losses Through Time}

The planet's hottest and largest desert is the Sahara which, in size, is about that of China. During the African Humid Period from about 15,000 to 5,000 years BP, the area of present-day Egypt contained an ungulate assemblage which included hippos (Hippopotamus amphibious), black rhinos (Diceros bicornis), and elephants as well as two species of zebra (Equus grevyi and Equus quagga), one ass (Equus asinus), giraffe (Giraffa camelopardalis), and wildebeest. There were warthog (Phacochoerus aethiopicus), wild single-humped camels (Camelus dromedaries), and African Cape buffalo. Included within this realm were ibex (Capra ibex), Barbary sheep (Ammotragus lervia), and small gazelles (Gazella leptocero and Gazella dorcas). The large carnivores were spotted hyenas (Crocuta crocuta), lions, cheetahs (Acinonyx jubatus), leopards, and wild dogs (Lycaon pictus) (Yeakel et al., 2014).

At about 5,000-6,000 years ago, faunal collapse began as aridity increased and as modern human populations grew. The original fauna of 37 large mammal fauna lost more than $75 \%$ of its species and, for ungulates, only gazelles, ibex, and Barbary sheep persisted. The loss of marine moisture and humidity destabilized the faunal assemblage as the Serengeti-like predator-prey system shriveled (Yeakel et al., 2014; Yeakel and Dunne, 2015).

\section{The Great Basin-a Restructured Prey-Predator System}

The large mammal fauna of North America's present Great Basin Desert is far more simple than that of late Holocene. Geographically, the biome encompasses most of Nevada and western Utah and the size in total is $\sim 500,000 \mathrm{~km}^{2}$ of temperate desert, nearly 50\% larger than California. In the late Holocene, there were three species of wild equids, a tapir, three camelids, three species of pronghorn, a mastodont, a mammoth, and a gomphothere. Among the large carnivores were giant short-faced bear, sabertooth, Scimitar cat, and American cheetah (Grayson, 2011). In the late Holocene, this fauna, like that of the Sahara, diminished with complete extinction. Of the species mentioned above, only pronghorn survives there today. The causes have variously been debated (Martin and Klein, 1984; MacPhee, 2019), but it is the consequent change in food webs that is pertinent to how well future changes may be anticipated in the still dynamic Great Basin.

Based on archeological, pre-historic, and ethnographic accounts from the first European explorers in the 18th century to those a century later, the Great Basin was an admixture of grassland and shrub. Pronghorn and bighorn were the most commonly witnessed species, elk and deer were rare to nonexistent, and few reports noted wolves or grizzly bears (Grayson, 2011; Lackey et al., 2013). Three species of hares occurred. By 1980, there were more than 300,000 cattle, 270,000 domestic sheep and goats, and some 30,000 feral horses (Berger, 1986); the vegetation that dominated a century earlier had been changed by excessive numbers of livestock (Young and Sparks, 2002), and 
differing seral phases supported irruptive mule deer populations. Subsequently, mountain lions followed, and in addition to mule deer as their primary prey, local populations of both porcupines (Erethizon dorsatum) and bighorn sheep were driven to nearextinction (Sweitzer et al., 1997; Gibson, 2006). Currently, cougars are widespread throughout the Great Basin, and black bears are re-colonizing this low-human-density landscape where once they had been extirpated (Malaney et al., 2018). Elk are expanding (Figure 5).

In this arid landscape where 150 years ago there were no indications of horses, mule deer, and cougar, all now persist. The system has changed. First, the vegetation was altered as a consequence of intense herbivory by exotics. It is now dominated by cheat-grass and expansive native shrubs (Grayson, 2011). Second, the large mammal fauna now present was likely not predictable 100 years ago.

\section{Central Asia-the Cashmere Conundrum in Context}

The planet's deserts and semi-arid grasslands support massive numbers of livestock (Batsaikhan et al., 2014), and together with humans, domestics may account for $>97 \%$ of global mammalian biomass (Bar-On et al., 2018). As drivers of terrestrial ecosystems, we have replaced apex carnivores and, through our control of predators and livestock, exerted strong direct and indirect effects on food webs by our chosen human livelihoods (Ekernas et al., 2017).

The Central Asia region, especially the Gobi Desert and the Tibetan Plateau areas of India and China, is unique in this regard for two principal reasons: first, its extant fauna is the only place remaining on Earth where the large mammal community may represent what existed in Beringia during the late Pleistocene (Guthrie, 1990); and second, domestic goats (Capra aegagrus) from Mongolia and China are responsible for $90 \%$ of the world's cashmere production. Italy, the United Kingdom, and Japan are the largest direct importers; most of the United States's cashmere derives from Italy. Consequently, the pairing of human socialecological systems is easily viewed as being driven by distant fashion interests and mediated by economic incentives, notably the multi-billion garment industry (Berger et al., 2013). We describe the context below.

First, the present large mammals of central Asia include wild yak (Bos mutus) and wild Bactrian camels (Camelus bactrianus) (both endangered), chiru (Pantholops hodgsoni), saiga, ibex (Capra sibirica), blue sheep (Pseudois nayaur), several species of gazelles, three wild equids (khulan, kiang, and Przewalski horses), and Argali sheep (Ovis ammon) among others as well as dholes (Cuon alpinus), wolves, brown bears, and snow leopards (Panthera uncia) (Schaller, 1998; Harris, 2008). The high alpine steppes and deserts have, in common, ecological equivalents from the cold dry steppes of late Holocene Beringia. Instead of Alaskan bison are wild yaks, and in place of migratory caribou are chiru and saiga. Rather than Dall sheep are argali, and kiangs, khulans, and Przewalki horses fill niches putatively held by Yukon and Alaska wild equids. Although Beringia lost all of these species, including its camelids, each of the Asian surrogates inhabits some realms of the continents' deserts, mountains, or high plateaus as does an impressive assortment of domesticated ungulates-sheep, goats, and cattle as well as domestic but free-ranging Bactrian camels, yaks, and horses (Berger, 2018).

Second, the coupling of human-socio-ecological systems is evident in the presence of these domestic ungulates which, in some form, co-inhabit many of the protected areas spanning the Tibetan Plateau and the Himalayan realms of high-elevation India and China and to the Gobi Desert in Mongolia (Figure 6). The largest protected region-The Chang Tang National Nature Reserve-at about $330,000 \mathrm{~km}^{2}$ is New Mexico-sized and the 3rd largest terrestrial protected area in the world. The biomass of ungulates in the Chang Tang along with that in six other protected areas comprises on average > 95\% domestic species. Within these broader realms are at least eight endemic ungulates-saiga, chiru, wild Bactrian camel, khulan, kiang, takhi (E. przewalskii), Przewalski's gazelles (Procapra przewalskii), and wild yak, all formally classified as endangered. At Mongolian and Indian sites, time series data indicate that domestic goats have increased disproportionately, about four times more, than other livestock in about three decades (Berger et al., 2013). A consequence of this proliferating trend in small livestock is an increase in human-wildlife conflicts, many involving carnivores (Mishra et al., 2004, 2010) and frequently free-ranging dogs (Young et al., 2011).

Local Mongolian cashmere herders-the only realm for which we have direct data-benefit economically from foreign markets where their profit margins for cashmere have outpaced the cost of living and they reap profit margins in excess of fourfold (Berger et al., 2013). What this suggests is that there must be anticipation for fiscal rewards and, hence, not only have been flock sizes increasing but so has the proportion of goats, a trend that characterizes much of Central Asia (Namgail et al., 2010). The ecological costs of high stocking rates have been well chronicled from both short- and long-term perspectives on all continents (e.g., Du Toit et al., 2010).

Sustainable conservation requires a human face, yet across the Tibetan-Himalayan-Gobi landscapes, a system that once existed with minimal impacts to wildlife now experiences large ones (Figure 6). Bottom-up and top-down forces become indirect drivers of the system's food webs, but the principal driver is the western multi-billion dollar garment industry fueled through cashmere, not apex carnivores (Berger et al., 2013). Such findings are not dissimilar to the bushmeat trade in which European fishing interests indirectly govern the trade-off between African fishers and their propensity for illegal harvest of terrestrial wildlife (Brashares et al., 2004).

\section{The World's Highest Mountains}

The Himalayas and Andes each arose via distinct plate tectonics, and each houses a unique ungulate fauna. Both also currently experience unprecedented patterns of de-glaciation, and have been strikingly affected by human colonization, although the Himalayan region has been peopled longer (Aldenderfer, 2003). The two realms also undergo indirect modification by modern humans through climate alteration at a first tier and secondarily by direct human action. In the less densely populated Himalayas, the agents of change have been dogs, livestock, and tourism (see below). Unlike Central Asia, the southern 


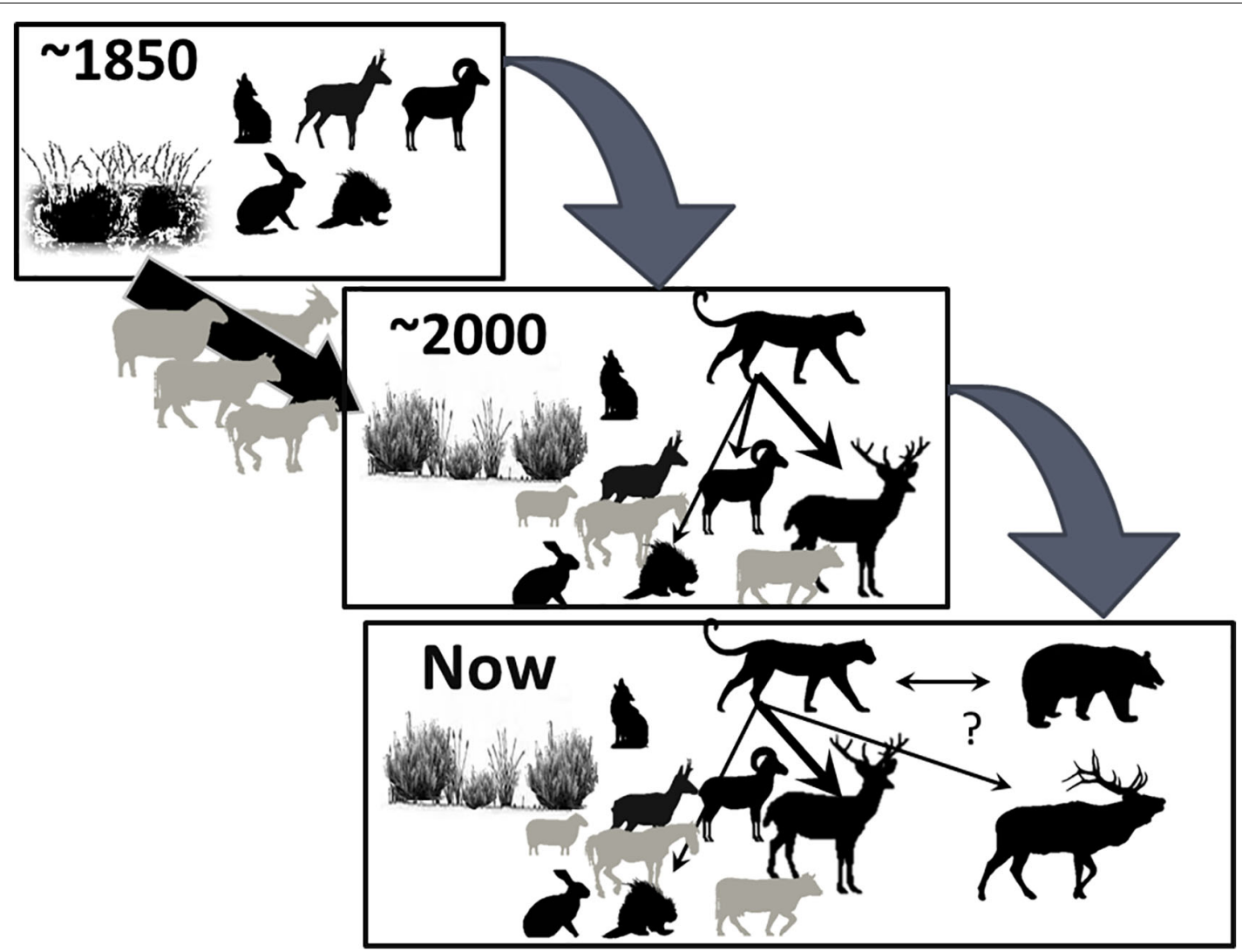

FIGURE 5 | Schematic of temporal change in a prey-predator food web in the Great Basin Desert, United States, illustrating how livestock and vegetation altered bottom-up processes to facilitate a new apex carnivore. The arrow width reflects the strength of predation intensity. The relative size of the icons depict a positive or a negative relationship, and in the lower illustration are pumas, black bear, coyotes, pronghorn, bighorn, mule deer, elk, hares, porcupines, domestic sheep, domestic horses, and cattle.

Andes abuts the ocean and disappear into the Patagonian Pacific where offshore influence modulates onshore ecosystems. These two cases offer twin but context-dependent histories, with changes to ungulates that would have been unanticipated several decades ago.

\section{The Himalayan Front}

As the Himalayas de-glaciated, wildlife and people colonized the northern reaches of India, Nepal, and Bhutan, including entry onto the Tibetan Plateau about more than 20,000 yBP (Chen et al., 2015). Along with pastoralists in what is now Bhutan are attendant domestic yaks and horses. Unlike the adjacent parts of the Tibetan Plateau where wild yaks and kiang had occurred, Bhutan has never had wild yaks or kiangs, presumably because there has been sufficient time for colonization as glacial recession has only been recent (Iwata and Narama, 2002). The initial pre-human faunas of highelevation sites in Nepal, Bhutan, and Ladakh in India had species like takin (Budorcas taxicolor), goral (Naemorhedus goral), red deer, blue sheep, and ibex. The current deglaciated habitats are obviously suitable-thousands of domestic horses and yaks use the high alpine grasslands and forests (Wangchuk et al., 2016).
Dogs too associate with domestic herds, sometimes with villagers and at other times with trekkers that they follow into new and less-peopled habitats where they encounter wild ungulates. India alone has $\sim 60$ million free-ranging dogs, and in both Bhutan and Nepal, as well as Tibet and through much of Asia, dogs prey on saiga, blue sheep, Argali, chiru, kiang, goral, ibex, sambar, chital, and blackbuck (Young et al., 2011; Home et al., 2018). In Bhutan, one of us (JB) witnessed multiple predation attempts on takin and blue sheep above treeline. These included up to four dogs in 11 attacks of takin; three of nine calves were individually separated from the groups and disappeared. Their fates remained unknown, although death appeared likely (Berger, 2018). Dogs, domestic yaks, and especially horses displaced takin from mineral licks, but beyond passive displacement or active predation, modern ungulate communities are being realtered in indirect if not direct ways through a profusion of domesticates (Figure 7).

Dogs can also be intermediate pathogenic hosts for zoonoses (Ministry of Agriculture and Forestry [MAGF], 2016). In Bhutan they affect yaks and may therefore indirectly influence people, and wildlife. Bhutanese high elevation dogs harbor tapeworms which, through the deposition of their eggs, are subsequently consumed from grasses by yaks. Coenurosis, a neurological 


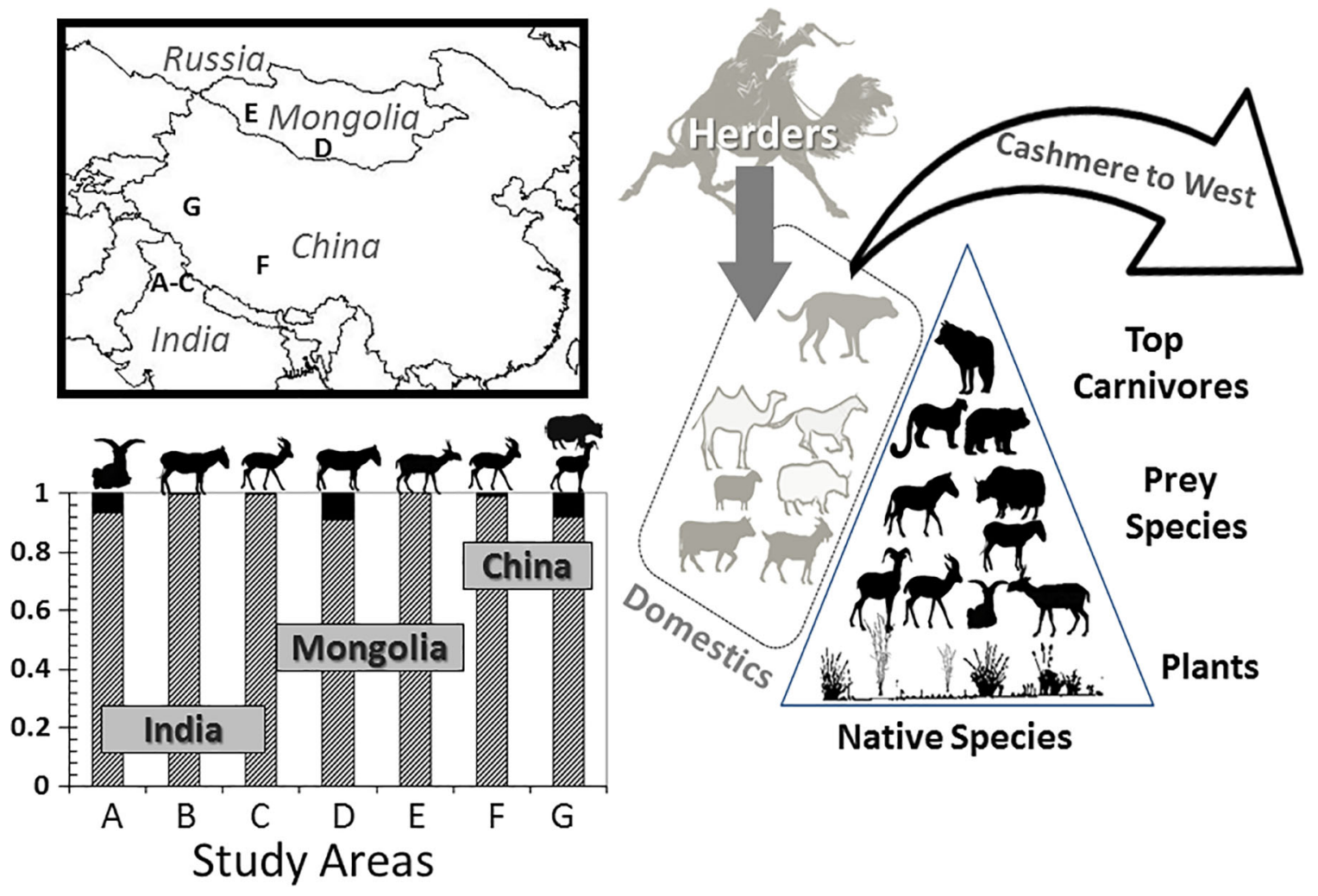

FIGURE 6 | Overview of the components of the cashmere trade to western consumers. Letters-protected areas where native (black bars) and domestic (stippled gray) ungulate biomass is expressed as a proportion of total. Icons from the left to the right are blue sheep, kiang, black-tailed gazelle, khulan, saiga, Przewalski gazelle, argali, and wild yak. The gray icons of domestics (top to bottom) are dogs, camels, horses, sheep, yaks, cattle, and goats. For native species, identified to leave are (top to bottom) wolves, snow leopards, and brown bears [specific study locales listed in Berger et al. (2013)].

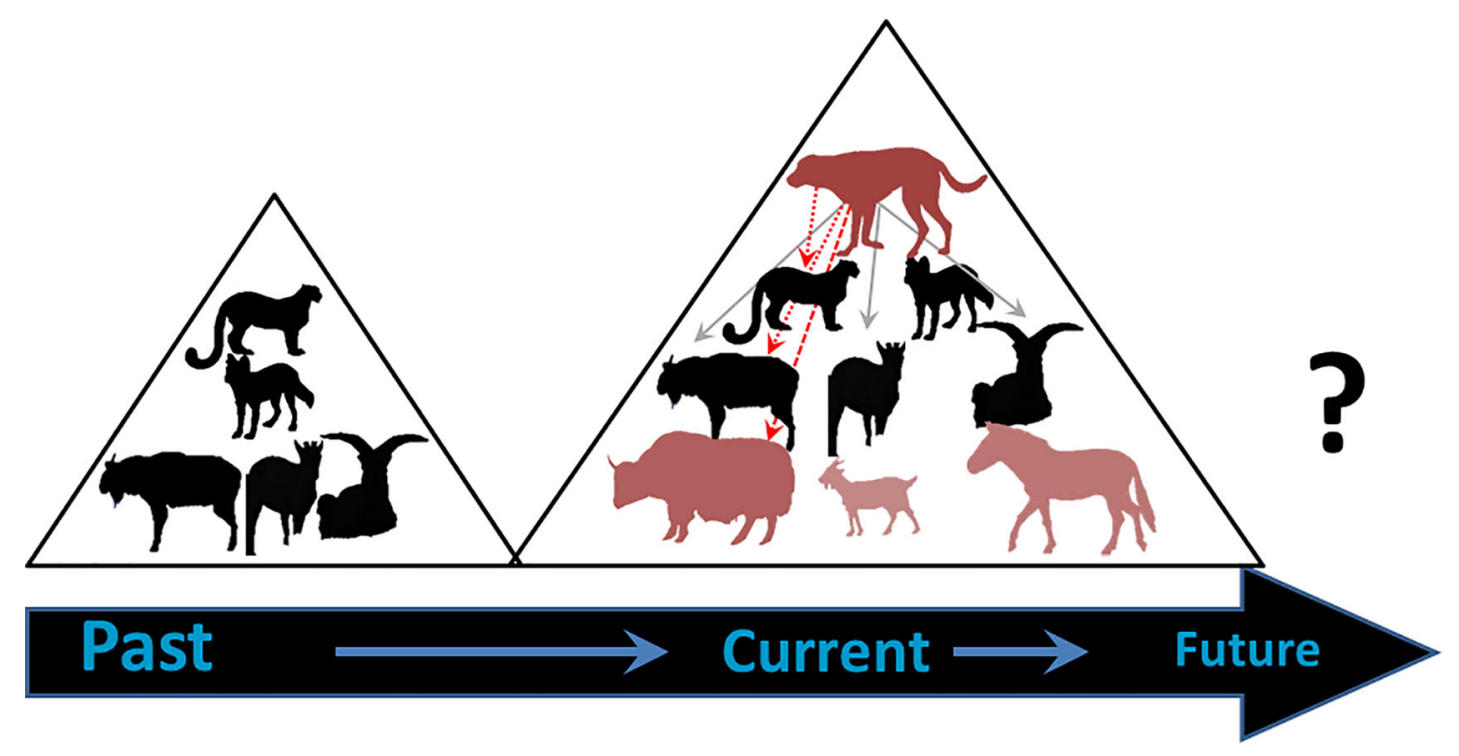

FIGURE 7 | Schematic overview of changes in a high-elevation Himalayan food web before and after pastoralism; this case study is from Bhutan's Jigme Dorji National Park (JDNP). The black icons represent native species, from top to bottom-snow leopard, dhole, takin, goral, blue sheep; the faded icons are sympatric domestics-dogs, yaks, goats*, horses. (*The goats are not in JDNP but exist in other parts of the Himalayas). 
disease, affects the brain and spinal cord and may result in $\sim 10 \%$ mortality of young and sub-adult yaks. It is unclear the extent to which takin, snow leopards, or other wild species experience effects of coenurosis. In Nepal, and similar to other parts of the world, disease associated with dogs such as rabies, canine distemper, and others of viral origin affect wild carnivores but the extent to which, if any, impacts high elevation food webs are unstudied (Ng et al., 2019).

Aside from dogs, other indirect effects may be mediated through human activity in high-elevation Tibetan and Himalayan native grassland and alpine zones. These activities involve the seasonal relocation of Indian, Nepalese, Bhutanese, Chinese, and Tibetan agro-pastoralist to high(er) summer elevations to collect the worm fungus Cordyceps (Ophiocordyceps sinensis). It is used, harvested, and marketed locally and internationally for medicinal purposes (Wangchuk and Wangdi, 2015). Prior to legalization in Bhutan in 2004, these high-elevation environs experienced minimal direct human disturbance. The indirect effects now of increasing numbers of villagers, horses, domestic yaks, and dogs to collection sites for Cordyceps are unknown but likely include the illicit harvest of wild animals, displacement of native species, and potentially disease transmission through dogs or yaks (Berger, 2018) as well documented declines in grassland quality (Wangchuk and Wangdi, 2015; Shrestha et al., 2019).

In Tibetan and Himalayan highlands, the decline in volume of $\sim 90 \%$ of glaciers is changing the lives of people, habitat quality, and water availability and restructuring animal communities (Xu et al., 2009; Lutz et al., 2014). Ungulates are affected through changes in ice and snow, the availability of snow patches, a profusion of roads, mining, and understandable and actionable improvements of livelihoods. The impacts on native species will not abate as more people are born in, or immigrate to, these highlands. Tourism will continue in a site-dependent fashion, but due to remoteness, it is likely that change will more directly involve indirect effects on people, livestock, other alien species, and business opportunities, coupled with climate change (Schaller, 2012; Berger et al., 2015).

\section{The Southern Andes-Hydrosphere, Harmful Algal Blooms, and Huemul}

While food webs are frequently viewed within discrete ecosystems, interactions that mix species from inter-connected marine and terrestrial environments are not rare (Torben and Erlandson, 2009). Hunter-gatherers in the North Pacific, for example, have had strong impacts on ecological statesas predicted by Holling's model (Figure 1)-which involved human alteration in sea otter abundance and kelp forests (Simenstad et al., 1978). Reliance on near-shore food by people as generalist foragers has occurred since their arrival in the Western Hemisphere more than 12,000 years ago (Dunne et al., 2016).

In addition to people, offshore climatic events and marine subsidies each produces ecological consequences for nearby mammals on land (Polis and Hurd, 1996; Stempniewicz et al., 2017). Ungulates adjacent to coastal zones including moose, mountain goats (Oreamnos americana), and red deer use unusual strategies that sometimes involve consuming kelp (CluttonBrock et al., 1982; Spaeth et al., 2001; White et al., 2018).
Hippos (Hippopotamus amphibious) sometimes surf (Geer et al., 2016). More dramatic effects occur when low-pressure weather fronts bring heavy snow or-with warming winter temperaturesrain-on-snow winter episodes which subsequently shape life histories, vital rates, and population dynamics. Arctic reindeer and muskoxen (Ovibos moschatus) are reciprocally affected by Atlantic and Pacific events (Post et al., 2009, 2013; Tyler et al., 2008; Berger et al., 2018). Aside from direct and indirect bottom-up forces that impact food accessibility, other pathways exist in which offshore processes affect those onshore. Marine cyanobacteria influence food security for fishermen (Berdalet et al., 2016). Their economic well-being may result in a greater intensity of harvest on huemul, the Western Hemisphere's rarest large mammal. Ensuing terrestrial impacts stem from interactions among disease, livestock, and dogs (Ritchie et al., 2013; Doherty et al., 2017; Flueck and Smith-Flueck, 2017), all of which conflate because of humans and may indirectly and directly impact huemul.

Known as the Andean mountain deer, huemul are scattered in $\sim 100$ small disconnected populations, are a critically endangered species, and are estimated at fewer than 2,000 individuals (Vila et al., 2010; Corti et al., 2011). As Chile's national mammal, huemul have graced its Coat of Arms (along with condors) since 1834. They once ranged to the Atlantic coast of southern Argentina where they were reported by Darwin (Diaz, 1993), but only disjunct populations remain on the east and the west slopes of the southern Andes (Povilitis, 1986, 2002). Their altitudinal range is from sea level to $\sim 2,000 \mathrm{~m}$; abundance increases toward the distal edges of the massive Patagonia Ice Fields (Frid, 2001; Briceño et al., 2013; González and Alvarado, 2017) where the sub-Antarctic continental ice sheets undergo immense melting (Sakakibara et al., 2013; Foresta et al., 2018). The resultant periglacial zones, particularly in and around Patagonia's largest protected area, the $\sim 35,000-\mathrm{km}^{2}$ Bernardo O'Higgins National Park (Figure 8), appear fundamental to huemul persistence (Povilitis, 1986; Frid, 1994, 1997, 1999; Briceño et al., 2013). The Patagonian Ice Field realm is also the least peopled area of South America, in part due to foreboding weather, massive fjords, and challenges associated with life in remote areas. Consequently, knowledge of trophic dynamics and huemul demography are limited (Corti et al., 2010; Vila et al., 2010; Häussermann et al., 2017; León-Muñoz et al., 2018).

Industrial fishing in the Patagonian coastal Chile is a key driver of the national economy (Urbina, 2016) where, like in the Arctic and the sub-Arctic, oceanic warming occurs in the sub-Antarctic waters (McCabe et al., 2016). Phytoplankton communities are at times being restructured by harmful algal blooms (HABs) in both the northern and the southern Pacific (Guzman et al., 2002; Cook et al., 2015). Operationally, HABs represent situations in which mollusks and crustaceans, fish, and marine mammals are affected by toxins associated with cyanobacteria and dinoflagellates (Wells et al., 2015). While the relationships between HAB and climate are affected by many factors and not well understood, warming marine environments are often associated with HAB (Edwards and Richardson, 2004; Alheit et al., 2005).

In southern Patagonia, these events were responsible for the planet's largest baleen whale mortality event, nearly $12 \%$ 

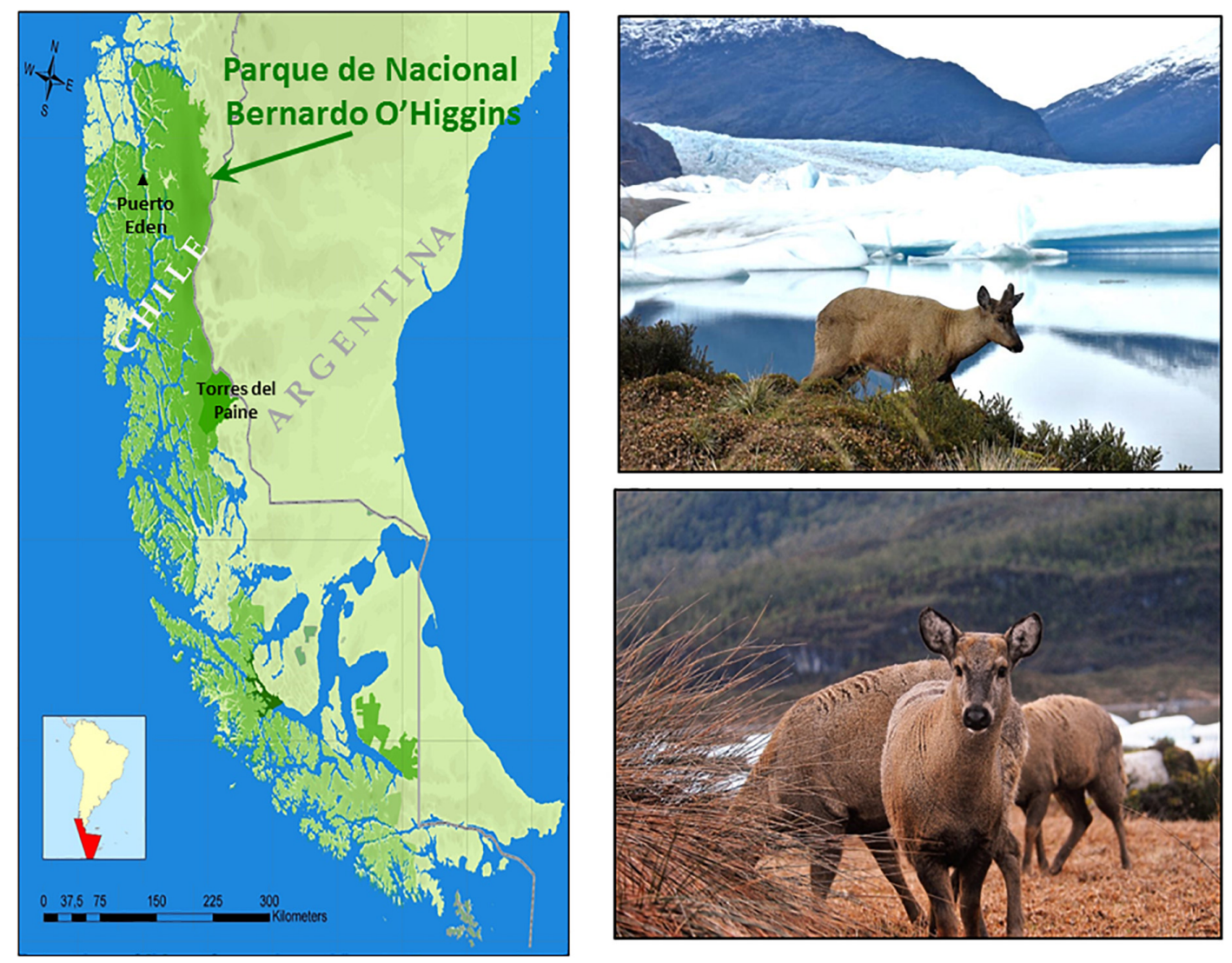

FIGURE 8 | Protected areas along the Patagonian coast in Chile (green) and the locale of its largest national park (Bernardo O'Higgins), its most visited (Torres del Paine), and the fishing village hamlet of Puerto Eden. Huemul male (top) and females (below) on re-vegetated spit with a recessing glacier backdrop.

reduction in the production of invasive salmon, and span unprecedented scales (Häussermann et al., 2017; León-Muñoz et al., 2018). As HABs proliferate, neurotoxin accumulation renders shellfish unfit for people and diseased fish-both farmed salmon and native species-diminish food security. Not only is public health a concern but also economic livelihoods reliant on fishing and crabbing industries are burdened. From a food web perspective, however, are probable indirect effects of climatedriven HABs on huemul (Figure 9).

Across southern Chile, HABs have concerned fishers for nearly half a century (Suarez and Guzman, 2005). Food security in remote coastal villages-whether Patagonia or elsewhere in the world-requires marine products like fish and mollusks, which at times are also buffered by the addition of a few sheep, livestock, or dogs. HABs obviate the possible consumption of marine products, and in many roadless communities, alternative foods from grocers are expensive, limited, or unavailable. One such isolated settlement is Puerto Eden, a hamlet of 200 people accessible only by boat (Frid, 1994, 2001; Vila et al., 2019). Situated within Bernardo O'Higgin's National Park where tidewater and other glaciers are recessing, huemul have colonized land spits between accumulated ice and vegetating moraines (Figure 9) up to $135 \mathrm{~km}$ from Puerto Eden and perhaps farther. Huemul density is inversely related to distance to human settlement (Briceño et al., 2013). If offshore events frame this relationship, four key assumptions must hold:

- Climate affects HABs with subsequent effects on human foods: The support for this tenant is generally strong as indicated from the studies referenced above. In short, the negative impacts on fisheries are modulated by warming oceanic temperatures. The climate effects on HABs are, however, complicated by contributions of glacial runoff, streams, and rivers to marine acidity, oxygen, and temperature.

- Remote coastal villagers enhance food security by accessing terrestrial-sourced nutrition: The assumption, although a truism, offers a framing to understand food and society in these distant realms. The sustainability of marine resources is of critical concern to the Chilean government given that loss or reduction of income has crucial economic consequences (Molinet et al., 2014). At a local scale, mollusks and fish are important dietary components in many fishing villages, and changes in their availability may be expected to reflect the pursuit of alternative foods. In Puerto Eden, bivalves are in frequent use as evidenced by shells piled up to $45 \mathrm{~cm}$ outside of homes; a small number of cattle and sheep are also maintained as additional sources 


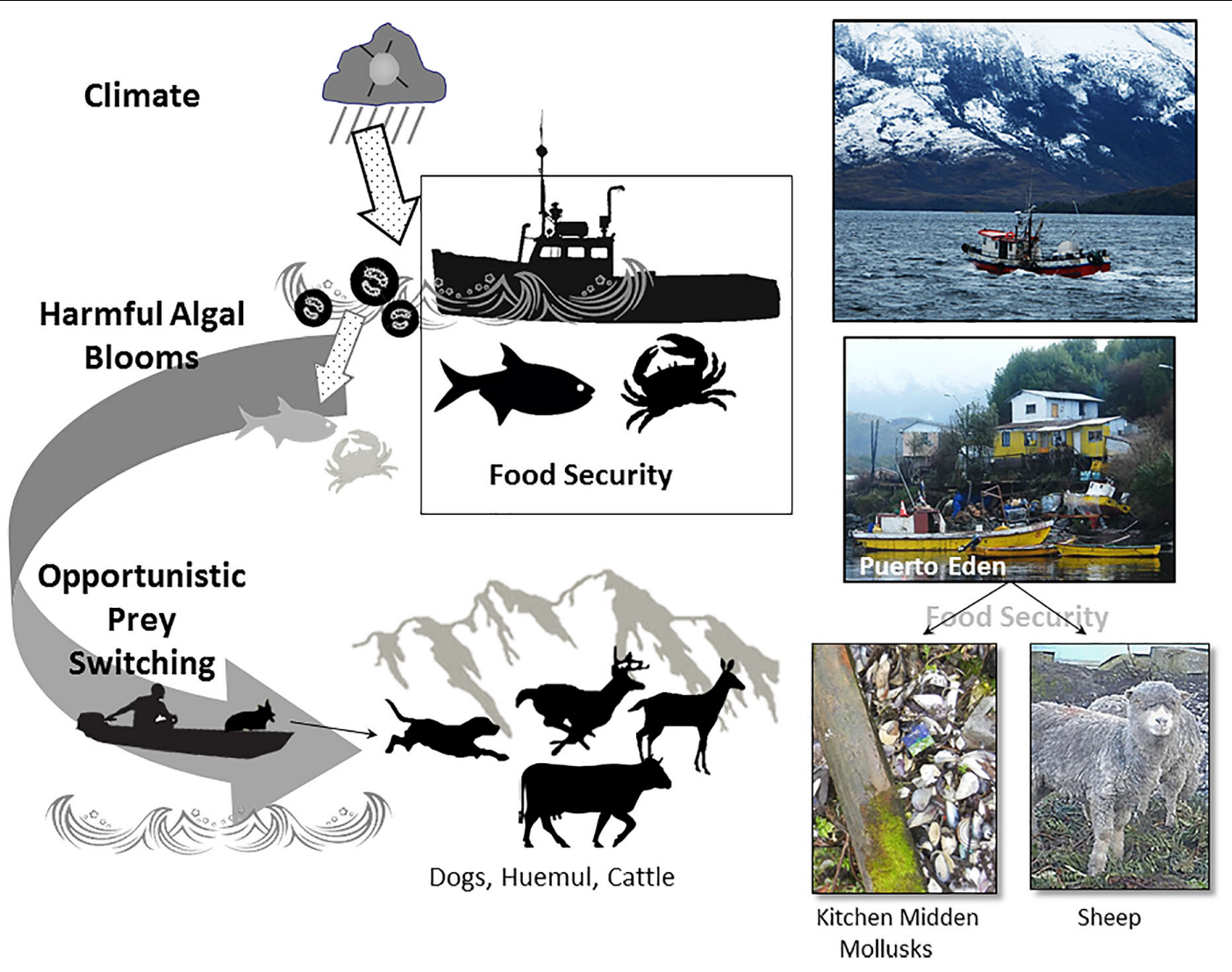

FIGURE 9 | Overview of demonstrated and hypothesized pathways by which climate and harmful algal blooms affect people and possibly huemul. Light gray fish and mollusks reflect higher-than-normal mortality and the testable proposition that HAB leads to elevated onshore foraging options. Fishing vessel (top) $30 \mathrm{~km}$ from Puerto Eden, bivalves outside a home, and sheep with thick wool-all photos are from Puerto Eden.

of protein (Figure 9). That people anywhere attempt to buffer against food shortages is unsurprising, yet to explore whether villagers experience malnourishment during $\mathrm{HAB}$ and subsequently alter their diets requires either time series data or spatial controls for analyses, neither of which is presently available.

- Fishermen hunt huemul during hard times: That people have always hunted is another truism. The critical issue is whether post-HAB human behavior increase huemul vulnerability to predation, a situation somewhat analogous to the harvest of bushmeat when African fisheries are no longer incentivized (Brashares et al., 2004). In deep coastal wet beech forests, huemul are difficult to find, so additional context is necessary to address the above issue.

Throughout Chile, free-ranging dogs are components of urban and rural society (Villatoro et al., 2019); they are also able predators of wild cervids (Silva-Rodríguez and Sieving, 2012), including huemul (Corti et al., 2010; Vila et al., 2010). In Puerto Eden, most artisanal fishing is by small wooden and fiberglass boats. In 2017, we noted that $19 \%$ of the 16 operational skiffs there had dogs visible. Resident communications with scientists including us reported that dogs were used to hunt huemul. When Frid (2001) studied on huemul two decades earlier, he indicated: "Hunters with dogs were present shortly before I began fieldwork (1994). Upon arriving at the site, we found recent tracks of humans with at least one dog. Although the Puerto Edén residents I interviewed could not estimate the hunting rate ... one hunter claimed that he kills 10-15 huemuls a year. He always uses dogs to corner them." Clearly, fishermen supplement diets with deer meat from fjords $100 \mathrm{~km}$ in distance, but data to test the tenet that harvest increases as a consequence of HABs are unavailable.

In contrast, what is clear is that five of eight sites where huemul were present 15 years ago are now gone. Only at the two most remote fjords-locales where park rangers sporadically visit-and at an additional site closer to Puerto Eden where some tourist traffic occur do huemul persist. According to government authorities (internal private communications) of the Chilean National Forest Service, unfrequented realms are sites where dogs are released to hunt huemul.

- Alternative human food indirectly affects huemul persistence: Despite the maintenance of a few farm animals in Puerto Eden to enhance local cuisine and dietary options, villagers make use of terrestrial environs, presumably as an additional measure to assure food security. Beyond hunting with dogs (above), huemul are 
also indirectly affected. In 1991, 18 cattle were transported by skiff and illegally released into the remote Tempanos Fjord (Frid, 1994, 2001). Their numbers reached several hundred when removed by the government in 2004 (Frid, 1997; Briceño et al., 2013). Huemul incurred 40\% mortality and $80 \%$ morbidity from 2005 to 2010 as severe clinical signs of foot disease were consistent with a parapoxvirus (Vila et al., 2019).

Coastal impacts on huemul occur through direct (e.g., illegal harvest using boat-transported dogs) and indirect (disease transmission through cattle) human-prompted actions. As throughout the world, livelihoods benefit by the use of marine resources. While its plausible that the climate-HAB connection motivates villagers in Puerto Eden to seek resources on land that subsequently encumber huemul-as speculated above-additional data on fisheries economics and the timing of subsequent behavior on land associated with huemul are needed to test the predictions.

\section{CONCLUSION-RELUCTANT LESSONS AND COMMUNITY REASSEMBLY IN A GRAVE WORLD}

Human impacts on the planet are grave and continue to downgrade natural diversity in ways that were not predictable 50 years ago (Estes et al., 2012). New pathogens affect coldadapted mammals (Kutz et al., 2009). Feral hogs occur on all continents (except Antarctica) and in $70 \%$ of the states of the United States, where their effects at landscape levels disrupt vertebrate communities, plants, and soils (McClure et al., 2018; Lewis et al., 2019). It is nearly impossible to consider communities of large herbivores and their assembly in the absence of understanding the modern human milieu regardless of whether human population growth (Ehrlich and Holdren, 1971) is detached or coupled with globalization (Pimentel et al., 1997; Chanda, 2008). We have lost or reduced the range of many large apex predators due to fear, persecution for economic reasons, or attrition simply by habitat conversion and loss of prey (Ray et al., 2005). The sole exception from food web perspectives may be in extreme environments-the highest peaks, the bleakest deserts, or the end of land, something noted by Darwin (1859): "When we reach .... absolute deserts, the struggle for life is almost exclusively with the elements. Not until we reach the extreme confines of life, in the Arctic regions or on the borders of an utter desert, will competition cease." Such cases, as noted by Darwin are, however, not only far from the norm, but the world has indubitably changed.

The United States has 12 native ungulates. The national parks in the United States have more than twice that number of free-ranging non-native ungulates (Plumb et al., 2014). Relationships are interminably mixed and interactions differ from what occurred before the European occupation of those or adjacent lands.

Only a few of the 420 park units are sufficiently sized to reveal insights into ecological baselines (Colwell et al., 2012; Berger,
2017), and yet even those the size of Yellowstone, Denali, or Canada's Wood Buffalo have had serious outside influence that affected the ecological dynamics within (Nishi et al., 2006; Smith and Ferguson, 2012; Geldmann et al., 2014). Serengeti and Kruger are no different (Sinclair et al., 2010). Only for parts of the Peruvian and the Brazilian Amazon, boreal Siberia and Canada, the Arctic, unfettered Himalayas, and a few realms of wild African is it possible to allow the continuance of established preypredator relationships (Schaller, 1998; Watson et al., 2016, 2018; Berger, 2018). Exotic ungulates and other species which affect ungulates are more the norm than exception. Wild hippos now occur in Colombia, banteng in Australia (Bradshaw et al., 2006), and gemsbok (Oryx gazella) and Barbary sheep in New Mexico. Burmese pythons were partly responsible for the collapse of the white-tailed deer where the former restructured the Everglades food web (Dorcas et al., 2012). Livestock and, later, cheat grass altered the habitats of the Great Basin which remain forever changed (Berger and Wehausen, 1991), and novel predator-prey relationships have emerged there (Figures 2, 6). The world's 400 million free-ranging dogs-through disease, predation, and displacement-have changed the face of carnivore and ungulate communities on every continent. Although not endemic to Australia and having been introduced some 4,000-5,000 years ago, dingoes are declared 'naturalized' and continue to change the Australian food webs (Healy S., 2007; Letnic and Koch, 2010). Courts in different parts of the world deem what is native and what is not, sometimes-like wolves with dog genes-ruling for the retention of species introgressed with domestics (Anderson et al., 2009). Chernobyl has moose, red deer, roe deer, and wild boar (Deryabina et al., 2015), Korea's Demilitarized Zone has reassembled with goral, Chinese water deer (Hydropotes inermis), and leopards (Healy H., 2007), and the West Bank between Israel and Jordan has some 80 wolves despite a few native hoofed mammals to consume. Restoration efforts continue (Hayward M. et al., 2019; Hayward M. W. et al., 2019).

Re-assembly reoccurs in ungulate communities in odd ways. While climate forcing is prominent globally and locally, human omnipresence rapidly modifies landscapes with no indication of abatement (Berger, 2018; Bowyer et al., 2019). Disease likewise runs rampant; hemorrhagic septicemia was responsible for the largest and most rapid mass ungulate die-off ever recorded in which $\sim 200,000$ saiga were killed in only 3 weeks (Fereidouni et al., 2019). The call-out to close 22 feed grounds that maintain thousands of elk for harvest in Wyoming has not changed across a century, although brucellosis continues and chronic wasting now enters the system where federal and state control of wildlife is still fought in the courts (Smith et al., 2004). Ceaseless tensions spill into other arenas. Advocacy groups argue for the retention of non-native species in national parks where federal rules are inconsistent. Mountain goats in Olympic National Park, for instance, were removed via mostly live captures in episodes spanning decades, and the shooting of them-in 2020already occurs in Grand Teton National Park. Just to the north in Yellowstone National Park, where goats are also not native, they remain untouched. Carnivores that prey on ungulates raise other issues. The Wyoming populace opposes wolves where-like jackrabbits and porcupines-they can be shot on site when outside 
certain bounds. In adjacent Colorado, wolf reintroduction will be decided by popular vote-Ballot Imitative \#107-in the general 2020 election, the result of 200,000 signatures by Coloradoans and announced by the Secretary of State in January 2020.

Biological interactions have shaped past and some current ungulate community structure. Far more common today are siteand species-dependent human interventions. These arise from politics, environmental and ecological disasters, war, harvest, and economics. Aldo Leopold famously said: "One of the penalties of an ecological education is that one lives alone in a world of wounds." The statement should resound loudly, yet lamenting the splendors of the past does little to better the future when unaccompanied by forethought and efforts to motivate conservation action among others. Although food webs with ungulates will not continue in the same fashion as they had in the past or even now-regardless of human presence-options to shape the future remain. These include the protection of big spaces and small species and a semblance of unencumbered habitat.

Incentives to coexist transcend the ethical as large mammals, like other species, deserve a right to be there, and public resolve should help assure that they play interactive ecological roles. Of note is that an estimated eight billion travelers visit protected areas annually (Balmford et al., 2015). Services associated with wildlife viewing are potent economic drivers in numerous African countries (World Tourism Organization, 2014), and in the United States, more than 300 million tourists per year visit national parks-a sum that collectively exceeds that for professional baseball, football, and basketball-where wildlife viewing is a goal (Beissinger et al., 2017).

During his exploration of South America in the 1830s, Darwin wrote about people, animals, plants, and even food webs (Darwin, 1859, 1889). Thirty years earlier, Alexander von Humboldt commented on the necessity to "recognize in the plant or the animal not merely an isolated species but a formed link in the chain of being to other forms" (von Humboldt, 1858), a clear allusion to the connectedness of nature whose food webs we reformat as we proliferate.

\section{Conservation Evolves}

Reintroductions continue, both of ungulates and carnivores in North America, Europe, Asia, and Africa. The issues of 19th and 20th century-overharvest, poaching, and wildlife slaughter-will not be the most pressing in the 21st century. Climate change already is, as is the direct and insidiously rapid destruction of habitat with associated changes in biodiversity. Some species rebound; others will be missed. The admixtures and loss we see today will differ yet again tomorrow. We may not embrace the change. With reluctance we must accept it, but not when or where we can make a difference to maintain what we have or restore what we have lost.

We conclude with two considerations: one is a thought exercise, the other is reality. First, it might be useful to query what would happen should the human stressors depicted in Figure 1 be removed. Would communities reassemble back to some basal, original state? We think not. If the supposition is correct, this then has implications for our reality check which involves conservation tactics while re-enforcing the value of large protected areas. Conservation practitioners should work fiercely to continue to protect what we have while simultaneously recognizing that disturbed habitat and altered communities still offer important contributions to beta biodiversity.

Moreover, we feel that scientists need to be more involved in policy direction, in speaking out, and in outreach. We recognize that this is more likely to occur, at least for academic scientists, after tenure, but a fairly easy fix is that university departments update tenure requirements to match our societal needs. While the research is critically important and publications help maintain our scientific credibility, we must make our science matter outside a narrow journal readership. Only by demonstrating to society the real relevance of the significance of food webs, biodiversity, and community composition will we be able to shape policy, motivate politicians and elected officials, and influence state and federal agencies. What we are engaged in is not an academic pursuit. The rich biological heritage of all living things, including the ungulates, is at stake.

\section{DATA AVAILABILITY STATEMENT}

The datasets generated for this study are available on request to the corresponding author.

\section{ETHICS STATEMENT}

The animal study was reviewed and approved by all universities where authors are currently based; specific studies indicate animal cares codes and approvals.

\section{AUTHOR CONTRIBUTIONS}

JB conceived the ideas of this manuscript through prolonged conversations with TW, AV, CB, and JL. Field work and data collection were in consort with TW, AV, and CB. JL conceptualized and debated portions of this manuscript, and all authors were involved in its writing.

\section{FUNDING}

Grants for specific manuscript are listed in relevant citations to the author's manuscript. Our respective institutions - the Bhutan Foundation, the Wildlife Conservation Society, and Colorado State University and the University of Colorado - supported the writing of this manuscript.

\section{ACKNOWLEDGMENTS}

Discussions across a near lifetime with Terry Bowyer, Jim Estes, Jodi Hilty, Elaine Leslie, Reed Noss, Barbara Saveedra, Kent Redford, Michael Soule, Peter Stacey, Kevin White, and Steve Zack helped crystalize the ideas herein. Matt Hayward, Evelyn Hunter Merrill, and Stan Boutin, and this volume's editors offered helpful suggestions to improve our manuscript. 


\section{REFERENCES}

Aldenderfer, M. S. (2003). Moving up in the world: archaeologists seek to understand how and when people came to occupy the Andean and Tibetan plateaus. Amer. Sci. 91, 542-549.

Alheit, J., Mollmann, C., Dutz, J., Kornilovs, G., Loewe, P., Mohrholz, V., et al. (2005). Synchronous ecological regime shifts in the central Baltic and the North Sea in the late 1980s. ICES J. Mar. Sci. 62, 1205-1215. doi: 10.1016/j.icesjms. 2005.04.024

Anderson, T. M., Candille, S. I., Musiani, M., Greco, C., Stahler, D. R., Smith, D. W., et al. (2009). Molecular and evolutionary history of melanism in North American gray wolves. Science 323, 1339-1343. doi: 10.1126/science.1165448

Arcese, P., and Sinclair, A. R. E. (1997). The role of protected areas as ecological baselines. J.Wildl. Manag. 61, 587-602. doi: 10.2307/3802167

Arthur, S. M., and Prugh, L. R. (2010). Predator-mediated indirect effects of snowshoe hares on Dall's sheep in Alaska. J. Wildl. Manag. 74, 1709-1721. doi: 10.2193/2009-322

Athreya, V., Odden, M., Linnell, J. D., Krishnaswamy, J., and Karanth, U. (2013). Big cats in our backyards: persistence of large carnivores in a human dominated landscape in India. PLoS One 8:e57872. doi: 10.1371/journal.pone.0057872

Atickem, A., Loe, L. E., and Stenseth, N. C. (2014). Individual heterogeneity in use of human shields by mountain Nyala. Ethology 120, 715-725. doi: 10.1111/eth. 12242

Augustine, D., and McNaughton, S. (2006). Interactive effects of ungulate herbivores, soil fertility, and variable rainfall on ecosystem processes in a semi-arid savanna. Ecosystems 9, 1242-1256. doi: 10.1007/s10021-005-0020-y

Baldi, R., Pelliza-Sbriller, A., Elston, D., and Albon, S. (2004). High potential for competition between guanacos and sheep in Patagonia. J. Wildl. Manag. 68, 924-938. doi: 10.2193/0022-541x(2004)068[0924:hpfcbg]2.0.co;2

Balmford, A., Green, J. M. H., Anderson, M., Beresford, J., Huang, C., Naidoo, R., et al. (2015). Walk on the wild side: estimating the global magnitude of visits to protected areas. PLoS Biol. 13:e1002074. doi: 10.1371/journal.pbio.1002074

Barboza, P. S., and Bowyer, R. T. (2000). Sexual segregation in dimorphic deer: a new gastrocentric hypothesis. J. Mamm. 81, 473-489. doi: 10.1093/jmammal/ 81.2.473

Barnosky, A. D., Koch, P. L., Feranec, R. S., Wing, S. L., and Shabel, A. B. (2004). Assessing the causes of late Pleistocene extinctions on the continents. Science 306, 70-75. doi: 10.1126/science.1101476

Barnowe-Meyer, K. K., White, P. J., Davis, T. L., and Byers, J. A. (2009). Predatorspecific mortality of pronghorn on Yellowstone's northern range. West. N. Am. Nat. 69, 186-194. doi: 10.3398/064.069.0207

Bar-On, Y. M., Phillips, R., and Milo, R. (2018). The biomass distribution on Earth. Proc. National Acad. Sci. U.S.A. 115, 6506-6511. doi: 10.1073/pnas.1711842115

Batsaikhan, N., Buuveibaatar, B., Chimed, B., Enkhtuya, O., Galbrakh, D., Ganbaatar, O., et al. (2014). Conserving the world's finest grassland amidst ambitious national development. Cons. Biol. 28, 1736-1739. doi: 10.1111/cobi. 12297

Bauer, H., Chapron, G., Nowell, K., Henschel, P., Funston, P., Hunter, L. T., et al. (2015). Lion (Panthera leo) populations are declining rapidly across Africa, except in intensively managed areas. Proc. Natl. Acad. Sci. U.S.A. 112, 14894-14899. doi: 10.1073/pnas.1500664112

Beissinger, S. R., Ackerly, D. D., Doremus, H., and Machlis, G. E. (2017). Science, Conservation, and National Parks. Chicago, IL: University of Chicago Press.

Benson, J. F., and Patterson, B. R. (2013). Moose (Alces alces) predation by eastern coyotes (Canis latrans) and eastern coyote $\times$ eastern wolf (Canis latrans $\times$ Canis lycaon) hybrids. Can. J. Zool. 91, 837-841. doi: 10.1139/cjz-2013-0160

Berdalet, E., Fleming, L. E., Gowen, R., Davidson, K., Hess, P., Backer, L. C., et al. (2016). Marine harmful algal blooms, human health and wellbeing: challenges and opportunities in the 21st century. J. Mar. Biol. Assoc. United Kingdom 96, 61-91. doi: 10.1017/S0025315415001733

Berger, J. (1986). Wild Horses of the Great Basin: Social Competition and Population Size. Chicago, IL: University of Chicago Press.

Berger, J. (2005). "Hunting by carnivores and by humans: is functional redundancy possible and who really cares," in Large carnivores and the conservation of biodiversity, eds J. Ray, et al. (Covello: Island Press), 316-341.

Berger, J. (2007a). Carnivore repatriation and Holarctic prey: narrowing the deficit in ecological effectiveness. Cons. Biol. 21, 1105-1116. doi: 10.1111/j.1523-1739. 2007.00729.x
Berger, J. (2007b). Fear, human shields and the redistribution of prey and predators in protected areas. Biol. Lett. 3, 620-623. doi: 10.1098/rsbl.2007.0415

Berger, J. (2008a). The Better to Eat You With: Fear in the Animal World. Chicago, IL: University of Chicago Press.

Berger, J. (2008b). Undetected species losses, food webs, and ecological baselines: a cautionary tale from the Greater Yellowstone Ecosystem. USA. Oryx 42, $139-142$.

Berger, J. (2017). "Science and challenge to conserve large wild mammals in 21st century american protected areas. Pp, 189-208," in Science for Parks and Parks for Science, eds S. Beissinger, D. D. Ackerly, H. Doremus, and G. E. Machlis, (Chicago, IL: University of Chicago Press).

Berger, J. (2018). Extreme Conservation: Life at the Edges of the World. Chicago, IL: University of Chicago Press.

Berger, J., Buvveibaatar, B., and Mishra, C. (2013). Globalization of the cashmere market and the decline of large mammals in Central Asia. Cons. Biol. 27, 679-689. doi: 10.1111/cobi.12100

Berger, J., Cain, S. L., and Berger, K. M. (2006). Connecting the dots: an invariant migration corridor links the Holocene to the present. Biol. Lety. 2, 528-531. doi: 10.1098/rsbl.2006.0508

Berger, J., Cheng, E., Krebs, M., Li, L., Kang, A., Schaller, G. B., et al. (2015). Legacies of past exploitation and climate affect mammalian sexes differently on the roof of the World - The Case of Wild Yaks. Sci. Rep. Nat. 5:8676. doi: $10.1038 /$ srep08676

Berger, J., and Cunningham, C. (1994). Bison: Mating and Conservation in Small Populations. New York, NY: Columbia University Press.

Berger, J., Hartway, C., Gruzdev, A., and Johnson, M. (2018). Climate degradation and extreme icing events constrain life in cold-adapted mammals. Sci. Rep. Nat. 8:1156. doi: 10.1038/s41598-018-19416-9

Berger, J., Stacey, P. B., Bellis, L., and Johnson, M. P. (2001a). A mammalian predator-prey imbalance: grizzly bear and wolf extinction affect avian neotropical migrants. Ecol. Appl. 11, 947-960. doi: 10.1890/1051-0761(2001) 011[0947:amppig]2.0.co;2

Berger, J., Swenson, J. E., and Per-Illson, I. (2001b). Re-colonizing carnivores and naive prey; conservation lessons from Pleistocene extinctions. Science 291, 1036-1039. doi: 10.1126/science.1056466

Berger, J., and Wehausen, J. (1991). Consequences of mammalian predator-prey disequilibrium in the Great Basin Desert. Cons. Biol. 5, 243-248.

Berger, K. M., and Gese, E. M. (2007). Does interference competition with wolves limit the distribution and abundance of coyotes? J. Anim. Ecol. 76, 1075-1085. doi: 10.1111/j.1365-2656.2007.01287.x

Berger, K. M., Gese, E. M., and Berger, J. (2008). Indirect effects and traditional trophic cascades: a test involving wolves, coyotes, and pronghorn. Ecology 89, 818-828. doi: 10.1890/07-0193.1

Blumstein, D. T., and Daniel, J. C. (2005). The loss of anti-predator behaviour following isolation on islands. Proc. R. Soc. B: Biol. Sci. 272, 1663-1668. doi: 10.1098/rspb.2005.3147

Boitani, L., and Linnell, J. D. (2015). Bringing large mammals back: large carnivores in Europe. In Rewilding European Landscapes. Cham: Springer, 67-84.

Bonacic, C., Almuna, R., and Ibarra, J. T. (2019). Biodiversity conservation requires management of feral domestic animals. Trends Ecol. Evol. 34, 683-686. doi: 10.1016/j.tree.2019.05.002

Bond, W. J. (2008). What limits trees in C4 grasslands and savannas? Ann. Rev. Ecol., Evol., Syst. 39, 641-659. doi: 10.1146/annurev.ecolsys.39.110707.173411

Bowyer, R. T., Bleich, V. C., Stewart, K. M., Whiting, J. C., and Monteith, K. L. (2014). Density dependence in ungulates: a review of causes, and concepts with some clarifications. Calif. Fish Game 100, 550-572.

Bowyer, R. T., Boyce, M. S., Goheen, J. R., and Rachlow, J. L. (2019). Conservation of the world's mammals: status, protected areas, community efforts, and hunting. J. Mamm. 100, 923-941. doi: 10.1093/jmammal/gyy180

Bowyer, R. T., Person, D. K., and Pierce, B. M. (2005). "Detecting top-down versus bottom-up regulation of ungulates by large carnivores: implications for conservation of biodiversity," in Large Carnivores and the Conservation of Biodiversity, eds J. Berger, R. Steneck, K. H. Redford, and J. C. Ray, (Covelo: Island Press), 342-361.

Bowyer, R. T., Van Ballenberghe, V., and Kie, J. G. (1997). "The role of moose in landscape processes: effects of biogeography, population dynamics, and predation," in Wildlife and Landscape Ecology, ed. J. A. Bissonette, (New York, NY: Springer), 265-287. doi: 10.1007/978-1-4612-1918-7_10 
Bradshaw, C. J., Isagi, Y., Kaneko, S., Bowman, D. M., and Brook, B. W. (2006). Conservation value of non-native banteng in northern Australia. Cons. Biol. 20, 1306-1311. doi: 10.1111/j.1523-1739.2006.00428.x

Brain, C., Forge, O., and Erb, P. (1999). Lion predation on black rhinoceros (Diceros bicornis) in Etosha National Park. Afr. J. Ecol. 37, 107-109. doi: 10.1046/j.13652028.1999.00137.x

Brashares, J. S., Arcese, P., Sam, M. K., Coppolillo, P. B., Sinclair, A. R., and Balmford, A. (2004). Bushmeat hunting, wildlife declines, and fish supply in West Africa. Science 306, 1180-1183. doi: 10.1126/science.1102425

Brashares, J. S., Prugh, L. R., Stoner, C. J., and Epps, C. W. (2010). "Ecological and conservation implications of mesopredator release," in Trophic Cascades: Predators, Prey, and the Changing Dynamics Of Nature, eds J. Terborgh, and J. E. Estes, (Washington, DC: Island Press), 221-240.

Briceño, C., L. A. Knapp, A. Silva, J. Paredes, I. Avendaño, A. Vargas, et al. (2013). Detecting an increase in an Endangered huemul Hippocamelus bisulcus population following removal of cattle and cessation of poaching in coastal Patagonia, Chile. Oryx 47, 273-279. doi: 10.1017/S0030605312000014

Caro, T. (2005). Antipredator Defenses in Birds and Mammals. Chicago, IL: University of Chicago Press.

Carthey, A. J., and Blumstein, D. T. (2018). Predicting predator recognition in a changing world. Trends Ecol. Evol. 33, 106-115. doi: 10.1016/j.tree.2017.10.009

Chanda, N. (2008). Runaway globalization without governance. Glob. Gov. Rev. Multilateralism Int. Org. 14, 119-125. doi: 10.1163/19426720-01402001

Chen, F. H., Dong, G. H., Zhang, D. J., Liu, X. Y., Jia, X., An, C. B., et al. (2015). Agriculture facilitated permanent human occupation of the Tibetan Plateau after 3600 BP. Science 347, 248-250. doi: 10.1126/science.1259172

Ćirović, D., Teodorović, V., Vasilev, D., Marković, M., Ćosić, N., Dimitrijević, M., et al. (2015). A large-scale study of the Trichinella genus in the golden jackal (Canis aureus) population in Serbia. Vet. Parasitol. 212, 253-256. doi: 10.1016/j.vetpar.2015.07.022

Clutton-Brock, J. (2012). Animals as Domesticates: A World View Through History. East Lansing, MI: MSU Press.

Clutton-Brock, T. H., Guinness, F. E., and Albon, S. D. (1982). Red Deer: Behavior and Ecology of Two Sexes. Chicago, IL: University of Chicago Press.

Colwell, R., Avery, S., Berger, J., Davis, G. E., Hamilton, H., Lovejoy, T., et al. (2012). Revisiting Leopold: Resource Stewardship in The National Parks. Washington, D.C: National Park System Advisory Board.

Cook, P. F., Reichmuth, C., Rouse, A. A., Libby, L. A., Dennison, S. E., Carmichael, O. T., et al. (2015). Algal toxin impairs sea lion memory and hippocampal connectivity, with implications for strandings. Science 350, 1545-1547. doi: $10.1126 /$ science.aac5675

Corti, P., Shafer, A. B., Coltman, D. W., and Festa-Bianchet, M. (2011). Past bottlenecks and current population fragmentation of endangered huemul deer (Hippocamelus bisulcus): implications for preservation of genetic diversity. Cons. Gen. 12, 119-128. doi: 10.1007/s10592-009-9997-7

Corti, P., Wittmer, H. U., and Festa-Bianchet, M. (2010). Dynamics of a small population of endangered huemul deer (Hippocamelus bisulcus) in Chilean Patagonia. J. Mamm. 91, 690-697. doi: 10.1644/09-mamm-a-047.1

Cote, S. D. (2005). Extirpation of a large black bear population by introduced white-tailed deer. Cons. Biol. 19, 1668-1671. doi: 10.1111/j.1523-1739.2005.00 252.x

Cote, S. D., Rooney, T. P., Tremblay, J.-P., Dussault, C., and Waller, D. M. (2004). Ecological impacts of deer overabundance. Ann. Rev. Ecol. Evol. Syst. 35, 113-147. doi: 10.1146/annurev.ecolsys.35.021103.105725

Croll, D. A., Maron, J. L., Estes, J. A., Danner, E. M., and Byrd, G. V. (2005). Introduced predators transform subarctic islands from grassland to tundra. Science 307, 1959-1961. doi: 10.1126/science.1108485

Cunningham, C., and Berger, J. (1997). Horn of Darkness; Rhinos on the Edge. Oxford: Oxford University Press.

Cypher, B. L., and Spencer, K. A. (1998). Competitive interactions between coyotes and San Joaquin kit foxes. J. Mamm. 79, 204-214. doi: 10.2307/138 2855

Darwin, C. (1859). On the Origin of Species by Means of Natural Selection. 1968 Reprint. London: Murray.

Darwin, C. (1889). Journal of Researches Into the Natural History and Geology of the Countries Visited During the Voyage of HMS"Beagle" Round the World, Under the Command of Capt. London: Ward, Lock and Company.
Davidson, A. D., Detling, J. K., and Brown, J. H. (2012). Ecological roles and conservation challenges of social, burrowing, herbivorous mammals in the world's grasslands. Front. Ecol. Environ. 10:477-486. doi: 10.1890/110054

Dayer, A. A., Redford, K. H., Campbell, K. J., Dickman, C. R., Epanchin-Niell, R. S., Grosholz, E. D., et al. (2019). The unaddressed threat of invasive animals in U.S. National Parks. Biol Invasions 22, 177-188. doi: 10.1007/s10530-019-02128-0

DeCesare, N. J., Hebblewhite, M., Robinson, H. S., and Musiani, M. (2010). Endangered, apparently: the role of apparent competition in endangered species conservation. Anim. Cons. 13, 353-362. doi: 10.1111/j.1469-1795.2009.00328.x

Derocher, A. E., Wiig, Ø, and Bangjord, G. (2000). Predation of Svalbard reindeer by polar bears. Polar Biol. 23, 675-678. doi: 10.1002/ar.22555

Deryabina, T. G., Kuchmel, S. V., Nagorskaya, L. L., Hinton, T. G., Beasley, J. C., Lerebours, A., et al. (2015). Long-term census data reveal abundant wildlife populations at Chernobyl. Cur. Biol. 25, R824-R826.

Diaz, N. I. (1993). Changes in the range distribution of Hippocamelus bisulcus in Patagonia. Zeit. fur Saugetier. 58, 344-351.

Doak, D. F., Estes, J. A., Halpern, B. S., Jacob, U., Lindberg, D. R., Lovvorn, J., et al. (2008). Understanding and predicting ecological dynamics: are major surprises inevitable. Ecology 89, 952-961. doi: 10.1890/07-0965.1

Doherty, T. S., Dickman, C. R., Glen, A. S., Newsome, T. M., Nimmo, D. G., Ritchie, E. G., et al. (2017). The global impacts of domestic dogs on threatened vertebrates. Biol. Cons. 210, 56-59. doi: 10.1016/j.biocon.2017.04.007

Dorcas, M. E., Willson, J. D., Reed, R. N., Snow, R. W., Rochford, M. R., Miller, M. A., et al. (2012). Severe mammal declines coincide with proliferation of invasive Burmese pythons in Everglades National Park. Proc. Nat. Acad. Sci. U.S.A. 7, 2418-2422. doi: 10.1073/pnas.1115226109

Du Toit, J., Kock, R., and Deutsch, J. (eds) (2010). Wild Rangelands: Conserving Wildlife while Maintaining Livestock in Semi-Arid Ecosystems. Oxford: Blackwell Publishing.

Dunne, J. A., Maschner, H., Betts, M. W., Huntly, N., Russell, R., Williams, R. J., et al. (2016). The roles and impacts of human hunter-gatherers in North Pacific marine food webs. Sci. Rep. 6:21179. doi: 10.1038/srep21179

Edwards, M. E., and Richardson, A. J. (2004). Impact of climate change on marine pelagic phenology and trophic mismatch. Nature 430, 881-883.

Ehrlich, P. (1968). The Population Bomb. New York, NY: Buccaneer Books. Emerson.

Ehrlich, P. R., and Holdren, J. P. (1971). Impact of population growth. Science 171, 1212-1217.

Eisenberg, J. F. (1981). The Mammalian Radiations: An Analysis of Trends in Evolution, Adaptation, and Behavior. Chicago, IL: University of Chicago Press.

Eisenberg, J. F., and Redford, K. H. (1989). Mammals of the Neotropics, Volume 2: The Southern Cone: Chile, Argentina, Uruguay, Paraguay, Vol. 2. Chicago, IL: University of Chicago Press.

Ekernas, L. S., Sarmento, W. M., Davie, H. S., Reading, R. P., Murdoch, J., Wingard, G. J., et al. (2017). Desert pastoralists' negative and positive effects on rare wildlife in the Gobi. Cons. Biol. 31, 269-277. doi: 10.1111/cobi.12881

Estes, J. A., Terborgh, J., Brashares, J. S., Power, M. E., Berger, J., Bond, W. J., et al. (2012). Trophic Downgrading of Planet Earth. Science 333, 301-306. doi: 10.1126/science.1205106

Fenton, M. B., Cumming, D. H., Rautenbach, I. L., Cumming, G. S., Cumming, M. S., Ford, G., et al. (1998). Bats and the loss of tree canopy in African woodlands. Cons. Biol. 12, 399-407. doi: 10.1046/j.1523-1739.1998.96376.x

Fereidouni, S., Freimanis, G. L., Orynbayev, M., Ribeca, P., Flannery, J., King, D. P., et al. (2019). Mass die-off of saiga antelopes, Kazakhstan, 2015. Emerg. Infect. Dis. 25:1169. doi: 10.3201/eid2506.180990

Festa-Bianchet, M., Coulson, T., Gaillard, J. M., Hogg, J. T., and Pelletier, F. (2006). Stochastic predation events and population persistence in bighorn sheep. Proc. Roy. Soc. Biol. Sci. 273, 1537-1543. doi: 10.1098/rspb.2006. 3467

Flueck, W. T., and Smith-Flueck, J. A. M. (2017). Troubling disease syndrome in endangered live Patagonian huemul deer (Hippocamelus bisulcus) from the Protected Park Shoonem: unusually high prevalence of osteopathology. BMC Res. Notes 10:739. doi: 10.1186/s13104-017-3052-4

Foresta, L., Gourmelen, N., Weissgerber, F., Nienow, P., Williams, J. J., Shepherd, A., et al. (2018). Heterogeneous and rapid ice loss over the Patagonian Ice Fields revealed by CryoSat-2 swath radar altimetry. Remote Sens. Environ. 211, 441-455. doi: 10.1016/j.rse.2018.03.041 
Frid, A. (1994). Observations on habitat use and social organization of a huemul Hippocamelus bisulcus coastal population in Chile. Biol. Conserv. 67, 13-19. doi: 10.1016/0006-3207(94)90003-5

Frid, A. (1997). Apocalypse cow: endangered deer compete with cattle for space in Chile's fjords. Wildl. Conserv. 100, 52-57.

Frid, A. (1999). Huemul (Hippocamelus bisulcus) sociality at a periglacial site: sexual aggregation and habitat effects on group size. Can. J. Zool. 77, 1083-1091. doi: 10.1139/z99-078

Frid, A. (2001). Habitat use by endangered huemul (Hippocamelus bisulcus): cattle, snow, and the problem of multiple causes. Biol. Cons. 100, 261-267. doi: 10.1016/s0006-3207(01)00064-7

Fryxell, J. M., Greever, J., and Sinclair, A. R. E. (1988). Why are migratory ungulates so abundant? Amer. Nat. 131, 781-798. doi: 10.1086/284822

Garrott, R. A., Bruggeman, J. E., Becker, M. S., Kalinowski, S. T., and White, P. J. (2007). Evaluating prey switching in wolf-ungulate systems. Ecol. Appl. 17, 1588-1597. doi: 10.1890/06-1439.1

Geer, A. V. D., Anastasakis, G., and Lyras, G. A. (2016). If hippopotamuses cannot swim, how did they colonize islands: a reply to Mazza. Lethaia 48, 147-150. doi: 10.1111/let.12095

Geffroy, B., Samia, D. S. M., Bessa, E., and Blumstein, D. T. (2015). How naturebased tourism might increase prey vulnerability to predators. Trends Ecol. Evol. 30, 755-765. doi: 10.1016/j.tree.2015.09.010

Geist, V. (1978). Life Strategies, Human Evolution, Environmental Design: Toward A Biological Theory of Health. Berlin: Springer-Verlag.

Geist, V. (1998). Deer of the World: Their Evolution, Behavior and Ecology. Harrisburg. Pennsylvania: Stackpole Books, 1998.

Geldmann, J., Joppa, L. N., and Burgess, N. D. (2014). Mapping change in human pressure globally on land and within protected areas. Cons. Biol. 28, 1604-1616. doi: $10.1111 /$ cobi.12332

Gibson, L. (2006). The role of lethal control in managing the effects of apparent competition on endangered prey species. Wildl. Soc. Bull. 34, 1220-1224. doi: 10.2193/0091-7648(2006)34[1220:trolci]2.0.co;2

Goetsch, C., Wigg, J., Royo, A. A., Ristau, T., and Carson, W. P. (2011). Chronic over browsing and biodiversity collapse in a forest understory in Pennsylvania: results from a 60 year-old deer exclusion plot. J. Torrey Bot. Soc. 138, 220-224.

Goldewijk, K. K. (2005). Three centuries of global population growth: a spatial referenced population (density) database for 1700-2000. Pop. Environ. 26, 343-367. doi: 10.1007/s11111-005-3346-7

González, B., and Alvarado, S. (2017). "What do we know about huemul abundance?", in El Huemul de Aysén y Otros Rincones, eds A. D. S. Iriarte, et al. (Aysen: Ediciones Secretaría Regional Ministerial de Agricultura de la Región de Aysén y Flora \& Fauna Chile Limitada), 109-121.

Graham, R. W., and Lundelius, E. L. Jr. (1984). "Coevolutionary disequilibrium and Pleistocene extinctions," in Quaternary Extinctions: A Prehistoric Revolution, eds P. S. Martin, and R. G. Klein, (Tucson: University of Arizona Press), 223-249.

Grayson, D. (2011). The Great Basin: A Natural Prehistory. Berkeley: University of California Press.

Grayson, D. K., Alroy, J., Slaughter, R., Skulan, J., and Alroy, J. (2001). Did human hunting cause mass extinction? Science 294, 1459-1462.

Grovenburg, T. W., Swanson, C. C., Jacques, C. N., Klaver, R. W., Brinkman, T. J., Burris, B. M., et al. (2011). Survival of white-tailed deer neonates in Minnesota and South Dakota. J. Wildl. Manag. 75, 213-220. doi: 10.1371/journal.pone. 0108797

Guthrie, R. D. (1990). Frozen Fauna of the Mammoth Steppe: The Story of Blue Babe. Chicago, IL: University of Chicago Press.

Guzman, L., Pacheco, H., Pizarro, G., and Alarcon, C. (2002). "Alexandrium catenella y veneno paralizante de los mariscos en Chile," in Floraciones Algales Nocivas en el Cono Sur Americano, eds E. Sar, M. Ferrario, and B. Reguera, (Madrid: Instituto Espan ol de Oceanograf $\imath$ 'a), 235-255.

Harihar, A., Pandav, B., and Goyal, S. P. (2011). Responses of leopard Panthera pardus to the recovery of a tiger Panthera tigris population. J. Appl. Ecol. 48, 806-814. doi: 10.1111/j.1365-2664.2011.01981.x

Harris, R. B. (2008). Wildlife Conservation in China: Preserving the Habitat of China's Wild West: Preserving the Habitat of China's Wild West. Abingdon: Routledge.

Häussermann, V., Gutstein, C. S., Bedington, M., Cassis, D., Olavarria, C., Dale, A. C., et al. (2017). Largest baleen whale mass mortality during strong El
Niño event is likely related to harmful toxic algal bloom. PeerJ 5:e3123. doi: 10.7717/peerj. 3123

Hayward, M., Edwards, S., Fancourt, B., Linnell, J., and Nilsen, E. (2019). “Topdown control of ecosystems and the case for rewilding: Does it all add up?," in Rewilding, eds N. Pettorelli, S. Durant, and J. Du Toit, (Cambridge: Cambridge University Press), 325-354. doi: 10.1017/9781108560962.016

Hayward, M. W., Scanlon, R. J., Callen, A., Howell, L. G., Klop-Toker, K. L., Di Blanco, Y., et al. (2019). Reintroducing rewilding to restoration-rejecting the search for novelty. Biol. Conserv. 233, 255-259. doi: 10.1016/j.biocon.2019.03. 011

Healy, H. (2007). Korean demilitarized zone: peace and nature park. Int. J. World Peace 24, 61-83.

Healy, S. (2007). Deadly dingoes: wild or simply requiring due process'? Soc. Stud. Sci. 37, 443-471. doi: 10.1177/0306312706070746

Hebblewhite, M. (2005). Predation by wolves interacts with the North Pacific Oscillation (NPO) on a western North American elk population. J. Anim. Ecol. 74, 226-233. doi: 10.1111/j.1365-2656.2004.00909.x

Hebblewhite, M., White, C. A., Nietvelt, C. G., McKenzie, J. A., Hurd, T. E., Fryxell, J. M., et al. (2005). Human activity mediates a trophic cascade caused by wolves. Ecology 86, 2135-2144. doi: 10.1890/04- 1269

Hess, A. N., Hess, R. J., Hess, J. L., Paulan, B., and Hess, J. A. (2014). American bison influences on lepidopteran and wild blue lupine distribution in an oak savanna landscape. J. Insect Cons. 18, 327-338. doi: 10.1007/s10841-0149640-x

Holling, C. S. (1973). Resilience and stability of ecological systems. Ann. Rev. Ecol. Syst. 4, 1-23. doi: 10.1146/annurev.es.04.110173.000245

Holling, C. S. (1986). "The resilience of terrestrial ecosystems; local surprise and global change," in Sustainable Development of the Biosphere, eds W. C. Clark, and R. E. Munn, (Cambridge: Cambridge University Press), 292-317.

Home, C., Bhatnagar, Y. V., and Vanak, A. T. (2018). Canine Conundrum: domestic dogs as an invasive species and their impacts on wildlife in India. Anim. Cons. 21, 275-282. doi: 10.1111/acv.12389

Isbell, L. A. (1990). Sudden short-term increase in mortality of vervet monkeys (Cercopithecus aethiops) due to leopard predation in Amboseli National Park. Kenya. Am. J. Primatol. 21, 41-52. doi: 10.1002/ajp.1350210105

Iwata, S., and Narama, C. (2002). Three Holocene and late Pleistocene glacial stages inferred from moraines in the Lingshi and Thanza village areas. Bhutan. Q. Int. 97, 0.69-78.

Jackson, J. B. (2008). Ecological extinction and evolution in the brave new ocean. Proc. Nat. Acad. Sci. U.S.A. 105(Suppl. 1), 11458-11465. doi: 10.1073/pnas. 0802812105

Jarman, P. J. (1974). The social organisation of antelope in relation to their ecology. Behaviour 48, 215-267. doi: 10.1163/156853974x00345

Kie, J. G., Bowyer, R. T., Nicholson, M. C., Boroski, B. B., and Loft, E. R. (2002). Landscape heterogeneity at differing scales: effects on spatial distribution of mule deer. Ecology 83, 530-544. doi: 10.1890/0012-9658(2002)083[0530: lhadse $] 2.0 . \mathrm{co} ; 2$

Koerner, S. E., and 72 members of the Grazing Exclosure Consortium, (2018). Change in dominance determines herbivore effects on plant biodiversity. Nat. Ecol. Evol. 2, 1925-1932. doi: 10.1038/s41559-018-0696-y

Krausman, P. R., and Bleich, V. C. (2013). Conservation and management of ungulates in North America. Int. J. Environ. Stud. 70, 372-382. doi: 10.1080/ 00207233.2013.804748

Kutz, S. J., Jenkins, E. J., Veitch, A. M., Ducrocq, J., Polley, L., Elkin, B., et al. (2009). The Arctic as a model for anticipating, preventing, and mitigating climate change impacts on host-parasite interactions. Vet. Parasit. 163, 217-228. doi: 10.1016/j.vetpar.2009.06.008

Lackey, C. W., Beckmann, J. P., and Sedinger, J. (2013). Bear historical ranges revisited: Documenting the increase of a once-extirpated population in Nevada. J. Wildl. Manag. 77, 812-820. doi: 10.1002/jwmg.548

Laliberte, A. S., and Ripple, W. J. (2004). Range contractions of North American carnivores and ungulates. BioScience 54, 123-138.

León-Muñoz, J., Urbina, M. A., Garreaud, R., and Iriarte, J. L. (2018). Hydroclimatic conditions trigger record harmful algal bloom in western Patagonia (summer 2016). Sci. Rep. 8, 1-10. doi: 10.1038/s41598-018-19461-4 Leopold, A. (1949). A Sand County Almanac and Sketches Here and There. (Outdoor Essays \& Reflections). Oxford: Oxford University Press. 
Letnic, M., and Koch, F. (2010). Are dingoes a trophic regulator in arid Australia? A comparison of mammal communities on either side of the dingo fence. Austr. Ecol. 35, 167-175. doi: 10.1111/j.1442-9993.2009.02022.x

Lewis, J. S., Corn, J. L., Mayer, J. J., Jordan, T. R., Farnsworth, M. L., Burdett, C. L., et al. (2019). Historical, current, and potential population size estimates of invasive wild pigs (Sus scrofa) in the United States. Biol. Invas. 21, 2373-2384. doi: 10.1007/s10530-019-01983-1

Loe, L. E., Hansen, B. B., Stien, A., Albon, S. D., Bischof, R., Carlsson, A., et al. (2016). Behavioral buffering of extreme weather events in a high-Arctic herbivore. Ecosphere 7:e01374.

Long, R. A., Wambua, A., Goheen, J. R., Palmer, T. M., and Pringle, R. M. (2017). Climatic variation modulates the indirect effects of large herbivores on smallmammal habitat use. J. Animl. Ecol. 86, 739-748. doi: 10.1111/1365-2656. 12669

Louthan, A., Valencia, E., Martins, D. J., Guy, T., Goheen, J., Palmer, T., et al. (2019). Large mammals generate both top-down effects and extended trophic cascades on floral-visitor assemblages. J. Trop. Ecol. 35, 185-198. doi: 10.1017/ s0266467419000142

Lovejoy, T. E., and Hannah, L. (eds) (2019). Biodiversity and Climate Change: Transforming the Biosphere. New Haven, CT: Yale University Press.

Loveridge, A. J., Hunt, J. E., Murindagomo, F., and Macdonald, D. W. (2006). Influence of drought on predation of elephant (Loxodonta africana) calves by lions (Panthera leo) in an African wooded savannah. J. Zool. 270, 523-530. doi: 10.1111/j.1469-7998.2006.00181.x

Lutz, A. F., Immerzeel, W. W., Shrestha, A. B., and Bierkens, M. F. P. (2014). Consistent increase in High Asia's runoff due to increasing glacier melt and precipitation. Nat. Clim. Change 4:587. doi: 10.1038/nclimate2237

MacPhee, R. D. (2019). End of the Megafauna. New York, NY: W. W. Nortoon and Company.

Malaney, J. L., Lackey, C. W., Beckmann, J. P., and Matocq, M. D. (2018). Natural rewilding of the Great Basin: genetic consequences of recolonization by black bears (Ursus americanus). Divers. Distrib. 24, 168-178. doi: 10.1111/ddi.12666

Martin, P. S., and Klein, R. G. (eds) (1984). Quaternary Extinctions: A Prehistoric Revolution. Tuscon: University of Arizona Press.

McCabe, R. M., Hickey, B. M., Kudela, R. M., Lefebvre, K. A., Adams, N. G., Bill, B. D., et al. (2016). An unprecedented coastwide toxic algal bloom linked to anomalous ocean conditions. Geophys. Res. Lett. 43, 10366-10376.

McClure, M. L., Burdett, C. L., Farnsworth, M. L., Sweeney, S. J., and Miller, R. S. (2018). A globally-distributed alien invasive species poses risks to United States imperiled species. Sci. Rep. 8:5331. doi: 10.1038/s41598-018-23657-z

McShea, W. J., and Rappole, J. H. (2000). Managing the abundance and diversity of breeding bird populations through manipulation of deer populations. Conserv. Biol. 14, 1161-1170. doi: 10.1046/j.1523-1739.2000.99210.x

McShea, W. J., Underwood, H. B., and Rappole, J. H. (eds) (1997). The Science of Overabundance: Deer Ecology and Population Management. Washington, DC: Smithsonian Institute Press.

Metz, M. C., Smith, D. W., Vucetich, J. A., Stahler, D. R., and Peterson, R. O. (2012). Seasonal patterns of predation for gray wolves in the multi-prey system of Yellowstone National Park. J. Anim. Ecol. 81, 553-563. doi: 10.1111/j.13652656.2011.01945.x

Middleton, A. D., Morrison, T. A., Fortin, J. K., Robbins, C. T., Proffitt, K. M., White, P. J., et al. (2013). Grizzly bear predation links the loss of native trout to the demography of migratory elk in Yellowstone. Proc. R. Soc. Biol. Sci. 280, 20130870. doi: 10.1098/rspb.2013.0870

Milner-Gulland, E. J., Kholodova, M. V., Bekenov, A., Bukreeva, O. M., Grachev, I. A., Amgalan, L., et al. (2001). Dramatic declines in saiga antelope populations. Oryx 35, 340-345. doi: 10.1046/j.1365-3008.2001.00202.x

Ministry of Agriculture and Forestry [MAGF], (2016). Bhutan. National Gid Disease Prevention and Control Plan launched. Available at: http://www.moaf. gov.bt/national-gid-disease-prevention-and-control-plan-launched (accessed January 9, 2020).

Mishra, C., Bagchi, S., Namgail, T., and Bhatnagar, Y. V. (2010). "Multiple use of trans-Himalayan rangelands: reconciling human livelihoods with wildlife conservation," in Wild Rangelands: Conserving Wildlife while Maintaining Livestock in Semi-arid Ecosystems, eds J. Du Toit, R. Kock, and J. Deutsch, (Oxford: Blackwell Publishing), 291-311. doi: 10.1002/9781444317091.ch11

Mishra, C., van Wieren, S. E., Ketner, P. I, Heitkonig, M. A., and Prins, H. H. T. (2004). Competition between domestic livestock and wild bharal Pseudois nayaur in the Indian Trans-Himalaya. J. Appl. Ecol. 41, 344-354. doi: 10.1111/ j.0021-8901.2004.00885.x

Molinet, C., Niklitschek, E. J., Coper, S., Díaz, M., Díaz, P. A., Fuentealba, M., et al. (2014). Challenges for coastal zoning and sustainable development in the northern Patagonian fjords (Aysén, Chile). Latin Am. J. Acquat. Res. 42, 18-29. doi: 10.3856/vol42-issue1-fulltext-2

Moran, M. D. (2014). Bison grazing increases arthropod abundance and diversity in a tall grass prairie. Environ. Entomol. 43, 1174-1184. doi: 10.1603/en14013

Namgail, T., Van Wieren, S. E., Mishra, C., and Prins, H. H. T. (2010). Multispatial co-distribution of the endangered Ladakh urial and blue sheep in the arid Trans-Himalayan mountains. J. Arid Environ. 74, 1162-1169. doi: 10.1016/ j.jaridenv.2010.04.013

Neff, P. K. K., Fettig, S. M., and VanOverbeke, D. R. (2007). Variable response of butterflies and vegetation to elk herbivory: an exclosure experiment in ponderosa pine and aspen-mixed conifer forests. Southwest. Nat. 52, 1-15.

Ng, D., Carver, S., Gotame, M., Karmasharya, D., Karmacharya, D., Pradhan, S. M., et al. (2019). Canine distemper in Nepal's Annapurna Conservation AreaImplications of dog husbandry and human behaviour for wildlife disease. PLoS One 14:e220874. doi: 10.1371/journal.pone.0220874

Nishi, J. S., Shury, T., and Elkin, B. T. (2006). Wildlife reservoirs for bovine tuberculosis (Mycobacterium bovis) in Canada: strategies for management and research. Vet. Microbiol. 112, 325-338. doi: 10.1016/j.vetmic.2005.11.013

Noss, R. F. (2012). Forgotten Grasslands of the South: Natural History and Conservation. Washington, DC: Island Press.

Novaro, A. J., Funes, M. C., and Jiménez, J. (2004). "Selection for introduced prey and conservation of culpeo and chilla zorros in Patagonia," in The Biology and Conservation of Wild Canids, eds D. W. MacDonald, and C. Sillero, (Oxford: Oxford University Press), 243-254.

Novaro, A. J., and Walker, R. S. (2005). "Human-induced changes in the effect of top carnivores on biodiversity in the Patagonian Steppe," in Large Carnivores and the Conservation of Biodiversity, eds J. C. Ray, et al. (Washington, DC: Island Press), 268-288.

Olson, K. A., Fuller, T. K., Schaller, G. B., Odonkhuu, D., and Murray, M. G. (2005). Estimating the population density of Mongolian gazelles Procapra gutturosa by driving long-distance transects. Oryx 39, 164-169. doi: 10.1017/ s0030605305000402

Owen-Smith, R. N. (1988). Megaherbivores: The Influence of Very Large Body Size on Ecology. London: Cambridge University Press.

Peterson, R. O. (2007). The Wolves of Isle Royale: a Broken Balance. Ann Arbor, MI: University of Michigan Press.

Pierce, B. M., Bleich, V. C., Monteith, K. L., and Bowyer, R. T. (2012). Topdown versus bottom-up forcing: evidence from mountain lions and mule deer. J. Mamm. 93, 977-988. doi: 10.1644/12-mamm-a-014.1

Pimentel, D., Huang, X., Cordova, A., and Pimentel, M. (1997). Impact of population growth on food supplies and environment. Pop. Env. 19, 9-14.

Plumb, G., Monello, R., Resnik, J., Kahn, R., Leong, K., Decker, D., et al. (2014). A Comprehensive Review of Ungulate Management by the National Park Service: Second Century Challenges, Opportunities, and Coherence. Washington DC: USDI.

Polis, G. A., and Hurd, S. D. (1996). Linking marine and terrestrial food webs: allochthonous input from the ocean supports high secondary productivity on small islands and coastal land communities. Amer. Nat. 147, 396-423. doi: $10.1086 / 285858$

Post, E., Bhatt, U. S., Bitz, C. M., Brodie, J. F., Fulton, T. L., Hebblewhite, M., et al. (2013). Ecological consequences of sea-ice decline. Science 341, 519-524.

Post, E., Forchhammer, M. C., Bret-Harte, M. S., Callaghan, T. V., Christensen, T. R., Elberling, B., et al. (2009). Ecological dynamics across the Arctic associated with recent climate change. Science 325, 1355-1358. doi: 10.1126/ science. 1173113

Povilitis, A. (1986). Huemuls in areas adjacent to glaciers in southern Chile. Mountain Res. Dev. 6, 273-275.

Povilitis, A. (2002). Current status of the huemul (Hippocamelus bisulcus) in central Chile. [El estado actual del huemul (Hippocamelus bisulcus) en Chile central]. Gayana 66, 59-68.

Power, J., and Compion, R. X. S. (2009). Lion predation on elephants in the Savuti, Chobe National Park, Botswana.". Afr. Zool. 44, 36-44.

Pringle, R. M., Young, T. P., Rubenstein, D. I., and McCauley, D. J. (2007). Herbivore-initiated interaction cascades and their modulation by productivity 
in an African savanna. Proc. Natl. Acad. Sci. U.S.A. 104, 193-197. doi: 10.1073/ pnas.0609840104

Prugh, L. R., Stoner, C. J., Epps, C. W., Bean, W. T., Ripple, W. J., Laliberte, A. S., et al. (2009). The rise of the mesopredator. Bioscience 59, 779-791. doi: 10.1525/bio.2009.59.9.9

Pyare, S., and Berger, J. (2003). Beyond demography and delisting: ecological recovery for Yellowstone's grizzly bears and wolves. Biol. Cons. 113, 63-73. doi: 10.1016/s0006-3207(02)00350-6

Quintana, N. T., Ballard, W. B., Wallace, M. C., Krausman, P. R., de Vos, J., Alcumbrac, O., et al. (2016). Survival of desert mule deer fawns in central Arizona. Southwest. Nat. 61, 93-101.

Ray, J., Redford, K. H., Steneck, R., and Berger, J. (eds) (2005). Large Carnivores and the Conservation of Biodiversity. Washington, DC: Island Press.

Redford, K. H. (1992). The empty forest. BioScience 42, 412-422. doi: 10.2307/ 1311860

Ripple, W. J., and Beschta, R. L. (2006). Linking a cougar decline, trophic cascade, and catastrophic regime shift in Zion National Park. Biol. Cons. 133, 397-408. doi: 10.1016/j.biocon.2006.07.002

Ripple, W. J., Estes, J. A., Beschta, R. L., Wilmers, C. C., Ritchie, E. G., Hebblewhite, M., et al. (2014). Status and ecological effects of the world's largest carnivores. Science 343:1241484. doi: 10.1126/science.1241484

Ripple, W. J., Newsome, T. M., Wolf, C., Dirzo, R., Everatt, K. T., Galetti, M., et al. (2015). Collapse of the world's largest herbivores. Sci. Adv. 1:e1400103. doi: $10.1126 /$ sciadv.1400103

Ripple, W. J., and Van Valkenburgh, B. (2010). Linking top-down forces to the Pleistocene megafaunal extinctions. BioScience 60, 16-526.

Ripple, W. J., Wolf, C., Newsome, T. M., Betts, M. G., Ceballos, G., Courchamp, F., et al. (2019). Are we eating the world's megafauna to extinction? Conserv. Lett. 12:12627.

Ritchie, E. G., Dickman, C. R., Letnic, M., Vanak, A. T., and Gommper, M. (2013). "Dogs as predators and trophic regulators," in Free-ranging Dogs and Wildlife Conservation, ed. M. E. Gommper, (New York, NY: Oxford University Press), 55-68. doi: 10.1093/acprof:osobl/9780199663217.003.0002

Rode, K. D., Robbins, C. T., Nelson, L., and Amstrup, S. C. (2015a). Can polar bears use terrestrial foods to offset lost ice-based hunting opportunities? Front. Ecol. Environ. 13:138-145. doi: 10.1890/140202

Rode, K. D., Wilson, R. R., Regehr, E. V., St, Martin M, Douglas, D. C., and Olson, J. (2015b). Increased land use by Chukchi Sea polar bears in relation to changing sea ice conditions. PLoS One 10:e142213. doi: 10.1371/journal.pone.0142213

Roemer, G. W., Gompper, M. E., and Van Valkenburgh, B. (2009). The ecological role of the mammalian mesocarnivore. Bioscience 59, 165-173. doi: 10.1093/ jhered/esx068

Rominger, E. M. (2018). The Gordian knot of mountain lion predation and bighorn sheep. J. Wildl. Manag. 82, 19-31. doi: 10.1002/jwmg.21396

Rooney, T. P. (2009). High white-tailed deer densities benefit graminoids and contribute to biotic homogenization of forest ground-layer vegetation. Plant Ecol. 202, 103-111. doi: 10.1007/s11258-008-9489-8

Rooney, T. P., and Waller, D. M. (2003). Direct and indirect effects of white-tailed deer in forest ecosystems. For. Ecol. Manag. 181, 165-176. doi: 10.1016/s03781127(03)00130-0

Sakakibara, D., Sugiyama, S., Sawagaki, T., Marinsek, S., and Skvarca, P. (2013). Rapid retreat, acceleration and thinning of Glaciar Upsala, Southern Patagonia Icefield, initiated in 2008. Ann. Glaciol. 54, 131-138. doi: 10.3189/ 2013aog63a236

Sanderson, E. W., Redford, K. H., Weber, B., Aune, K., Baldes, D., Berger, J., et al. (2008). The ecological future of the North American bison: conceiving long-term, large-scale conservation of wildlife. Cons. Biol. 22, 252-266. doi: 10.1111/j.1523-1739.2008.00899.x

Sarmento, W. M., and Berger, J. (2017). Human visitation limits the utility of protected areas as ecological baselines. Biol. Cons. 212, 316-326. doi: 10.1016/j. biocon.2017.06.032

Schaller, G. B. (1998). Wildlife of Tibetan Steppes. Chicago, IL: University of Chicago Press.

Schaller, G. B. (2012). Tibet Wild: A Naturalist's Journeys on the Roof of the World. Washington, DC: Island Press.

Schwartz, C. C., and Franzmann, A. W. (1991). Interrelationship of black bears to moose and forest succession in the northern coniferous forest. Wildl. Monog. $113,3-58$.
Serrouya, R., McLellan, B. N., Boutin, S., Seip, D. R., and Nielsen, S. E. (2011). Developing a population target for an overabundant ungulate for ecosystem restoration. J. Appl. Ecol. 48, 935-942. doi: 10.1111/j.1365-2664.2011.01998.x

Sharam, G. J., Sinclair, A. R. E., and Turkington, R. (2009). Serengeti birds maintain forests by inhibiting seed predators. Science 325, 51-51. doi: 10.1126/science. 1173805

Shrestha, U. B., Dhital, K. R., and Gautam, A. P. (2019). Economic dependence of mountain communities on Chinese caterpillar fungus Ophiocordyceps sinensis (yarsagumba): A case from western Nepal. Oryx 53, 256-264. doi: 10.1017/ s0030605317000461

Silva-Rodríguez, E. A., and Sieving, K. E. (2012). Domestic dogs shape the landscape-scale distribution of a threatened forest ungulate. Biol. Cons. 150, 103-110. doi: 10.1016/j.biocon.2012.03.008

Simenstad, C. A., Estes, J. A., and Kenyon, K. W. (1978). Aleuts, sea otters, and alternate stable-state communities. Science 200, 403-411. doi: 10.1126/science. 200.4340 .403

Simpson, G. G. (1944). Tempo and Mode in Evolution. New York, NY: Columbia University Press.

Sinclair, A. R. E., Mduma, S., and Brashares, J. S. (2003). Patterns of predation in a diverse predator-prey system. Nature 425, 288-290. doi: 10.1038/nature01934

Sinclair, A. R. E., Metzger, K., Brashares, J. S., Nkwabi, A., Sharam, G., and Fryxell, J. M. (2010). "Trophic cascades in African savanna: Serengeti as a case study," in Trophic Cascades: Predators, Prey and the Changing Dynamics of Nature, eds J. Terborugh, and J. E. Estes, (Washington, DC: Island Press), 255-274.

Smith, B., Cole, E. K., and Dobkin, D. S. (2004). An Imperfect Pasture: A Century of Change at the National Elk Refuge in Jackson Hole, Wyoming. Wyoming: Grand Teton Natural History Association.

Smith, D., and Ferguson, G. (2012). Decade of the Wolf: Returning the Wild to Yellowstone. Lanham, MA: Rowman \& Littlefield.

Smith, D. W., Peterson, R. O., and Houston, D. B. (2003). Yellowstone after wolves. BioScience 53, 330-340.

Smith, F. A., and Lyons, S. K. (eds) (2013). Animal Body Size: Linking Pattern and Process across Space, Time and Taxonomy. Chicago, IL: University of Chicago Press.

Smith, F. A., Tomé, C. P., Elliott Smith, E. A., Lyons, S. K., Newsome, S. D., and Stafford, T. W. (2015). (online); 2016. Unraveling the consequences of the terminal Pleistocene megafauna extinction on mammal community assembly. Ecography 39, 223-239. doi: 10.1111/ecog.01779

Soulé, M. E., Estes, J. A., Berger, J., and Del Rio, C. M. (2003). Ecological effectiveness: conservation goals for interactive species. Cons. Biol. 17, 12381250. doi: 10.1046/j.1523-1739.2003.01599.x

Spaeth, D. F., Hundertmark, K. J., Bowyer, R. T., Barboza, P. S., Stephenson, T. R., and Peterson, R. O. (2001). Incisor arcades of Alaskan moose: is dimorphism related to sexual segregation? Alces 37, 217-226.

Springer, A. M., Estes, J. A., Van Vliet, G. B., Williams, T. M., Doak, D. F., Danner, E. M., et al. (2003). Sequential megafaunal collapse in the North Pacific Ocean: An ongoing legacy of industrial whaling? Proc. Nat. Acad. Sci. U.S.A. 100, 12223-12228. doi: 10.1073/pnas. 1635156100

Stebbins, G. L. (1981). Coevolution of grasses and herbivores. Ann. Missouri Bot. Gard. 68, 75-86.

Stempniewicz, L., Goc, M., Kidawa, D., Urbański, J., Hadwiczak, M., et al. (2017). Marine birds and mammals foraging in the rapidly deglaciating Arctic fjordnumbers, distribution and habitat preferences. Clim. Change 140, 533-548. doi: 10.1007/s10584-016-1853-4

Stewart, K. M., Bowyer, R. T., Kie, J. G., Dick, B. L., and Ruess, R. W. (2009). Population density of North American elk: effects on plant diversity. Oecologia 161, 303-312. doi: 10.1007/s00442-009-1376-Z

Stoddart, L. C., Griffiths, R. E., and Knowlton, F. F. (2001). Coyote responses to changing jackrabbit abundance affect sheep predation. J. Range Manag. 54, 15-20.

Strong, D. R., Simberloff, D., Abele, L. G., and Thistle, A. B. (eds) (1984). Ecological Communities: Conceptual Issues and the Evidence. Princeton, NJ: Princeton Univ. Press.

Suarez, B., and Guzman, L. (2005). Floraciones de Algas Nocivas: Mareas Rojas y Toxinas Marinas. Santiago: Editorial Universitaria.

Sweitzer, R. A., Jenkins, S. H., and Berger, J. (1997). Near-extinction of porcupines by mountain lions and consequences of ecosystem change in the Great Basin Desert. Cons. Biol. 11, 1407-1417. doi: 10.1046/j.1523-1739.1997.96138.x 
Terborgh, J., and Estes, J. A. (eds) (2010). Trophic Cascades: Predators, Prey, and the Changing Dynamics of Nature. Washington, DC: Island Press.

Thomas, C. D. (2017). Inheritors of the Earth: How Nature is Thriving in an Age of Extinction. London: Hachette UK.

Torben, R. C., and Erlandson, J. M. (2009). Coastal exploitation: How did ancient hunter-gatherers influence coastal environments? Science 352, 952-953.

Trouwborst, A., Krofel, M., and Linnell, J. D. (2015). Legal implications of range expansions in a terrestrial carnivore: the case of the golden jackal (Canis aureus) in Europe. Biodiv. Conserv. 24, 0.2593-2610.

Tyler, N. J., Forchhammer, M. C., and Øritsland, N. A. (2008). Nonlinear effects of climate and density in the dynamics of a fluctuating population of reindeer. Ecology 89, 1675-1686. doi: 10.1890/07-0416.1

United Nations, Department of Economic, and Social Affairs, Population Division, (2019). World Population Prospects 2019: Ten Key Findings. New York, NY: United Nations.

Urbina, M. A. (2016). Temporal variation on environmental variables and pollution indicators in marine sediments under sea Salmon farming cages in protected and exposed zones in the Chilean inland Southern Sea. Sci. Total Environ. 573, 841-853. doi: 10.1016/j.scitotenv.2016.08.166

Van Duyne, C. V., Ras, E., De Vos, A. E. W., De Boer, W. F., and Henkens, R. J. H. G. (2009). Wolf predation among reintroduced Przewalski horses in Hustai National Park. Mongolia. J. Wildl. Manam. 73, 836-843. doi: 10.2193/ 2008-027

Vermeij, G. J. (1993). Evolution and Escalation: An Ecological History of Life. Princeton, NJ: Princeton University Press.

Vila, A. R., Briceño, C., McAloose, D., Seimon, T. A., Armién, A. G., Mauldin, E. A., et al. (2019). Putative parapoxvirus-associated foot disease in the endangered huemul deer (Hippocamelus bisulcus) in Bernardo O'Higgins National Park. Chile. PLoS One 14:e0213667. doi: 10.1371/journal.pone.021 3667

Vila, A. R., Lopez, R., Pastore, H., Faundez, R., and Serret, A. (2006). Current distribution and conservation of the huemul (Hippocamelus bisulcus) in Argentina and Chile. Mastozool. Neotrop. 13, 263-269. doi: 10.7717/peerj. 5222

Vila, A. R., Saucedo, C., Aldridge, D., Ramilo, E., and Corti, P. (2010). "South Andean huemul Hippocamelus bisulcus (Molina 1782)," in Neotropical Cervidology: Biology and Medicine of Latin American Deer, eds J. M. Duarte, and S. González, (Brazil: Funep), 89-100.

Villatoro, F. J., Naughton-Treves, L., Sepúlveda, M. A., Stowhas, P., Mardones, F. O., and Silva-Rodríguez, E. A. (2019). When free-ranging dogs threaten wildlife: Public attitudes toward management strategies in southern Chile. J. Environ. Manag. 229, 67-75. doi: 10.1016/j.jenvman.2018.06.035

von Humboldt, A. (1858). Cosmos: A Sketch of the Physical Description of the Universe, Vol. I, trans. E. C. Otte, (Baltimore, MA: The John Hopkins Press), 1997.

Vors, L. S., and Boyce, M. S. (2009). Global declines of caribou and reindeer. Glob. Change Biol. 15, 2626-2633. doi: 10.1111/j.1365-2486.2009.01974.x

Vrba, E. (1993). Turnover-pulses, the Red Queen, and Related Topic. Am. J. Sci. 293-A, 418-452. doi: 10.2475/ajs.293.a.418

Vrba, E. S., and Schaller, G. B. (2000). Antelopes, Deer, and Relatives. London: Yale University Press.

Walker, S., and Novaro, A. (2010). “The World's southernmost pumas in Patagonia and the Southern Andes," in Cougar Ecology and Conservation, eds M. Hornocker, and S. Negri (Chicago, IL: The University of Chicago Press), 91-100.

Wallace, A. R. (1876). The Geographical Distribution of Animals: With a Study of The Relations of Living and Extinct Faunas as Elucidating The Past Changes of The Earth's Surface, Vol. 1. Cambridge: Cambridge University Press, 2011.

Walston, J., Karanth, K. U., and Stokes, E. (2010). Avoiding the Unthinkable: What Will It Cost to Prevent Tigers Becoming Extinct in the Wild. New York, NY: Wildlife Conservation Society.

Wangchuk, K., and Wangdi, J. (2015). Mountain pastoralism in transition: Consequences of legalizing Cordyceps collection on yak farming practices in Bhutan. Pastoralism 5:4.

Wangchuk, T. R., Wegge, P., and Sangay, T. (2016). Habitat and diet of Bhutan takin Budorcas taxicolor whitei during summer in Jigme Dorji National Park. Bhutan. J. Nat. Hist. 50, 759-770. doi: 10.1080/00222933.2015.1079658

Watson, J. E., Shanahan, D. F., Di Marco, M., Allan, J., Laurance, W. F., Sanderson, E. W., et al. (2016). Catastrophic declines in wilderness areas undermine global environment targets. Cur. Biol. 26, 2929-2934. doi: 10.1016/j.cub.2016.08.049
Watson, J. E., Venter, O., Lee, J., Jones, K. R., Robinson, J. G., Possingham, H. P., et al. (2018). Protect the last of the wild. Nature 563, 27-30. doi: 10.1038/ d41586-018-07183-6

Webb, S. D. (2006). The great American biotic interchange: patterns and processes. Ann. Missouri Bot. Gard. 93, 245-258.

Webb, S. D., and Barnosky, A. D. (1989). Faunal dynamics of Pleistocene mammals. Ann. Rev. Earth Planetary Sci. 17, 413-436. doi: 10.1146/annurev.ea.17.050189. 002213

Weber, M., and Gonzalez, S. (2003). Latin American deer diversity and conservation: a review of status and distribution. Ecoscience 10, 443-454. doi: 10.1080/11956860.2003.11682792

Wells, M. L., Trainer, V. L., Smayda, T. J., Karlson, B. S., Trick, C. G., Kudela, R. M., et al. (2015). Harmful algal blooms and climate change: Learning from the past and present to forecast the future. Harmful Algae 49, 68-93. doi: 10.1016/j.hal.2015.07.009

Wemmer, C. (ed.) (1987). Biology and Management of the Cervidae: A Conference Held at the Conservation and Research Center, National Zoological Park, Smithsonian Institution, Front Royal, Virginia. Washington, D.C: Smithsonian Institution Press.

Wheatall, L., Nuttle, T. I. M., and Yerger, E. (2013). Indirect effects of pandemic deer overabundance inferred from caterpillar-host relations. Cons. Biol. 27, 1107-1116. doi: 10.1111/cobi.12077

White, K. S., Barten, N. L., Crouse, S., and Crouse, J. (2014). Benefits of migration in relation to nutritional condition and predation risk in a partially migratory moose population. Ecology 95, 225-237. doi: 10.1890/13-0054.1

White, K. S., Gregovich, D. P., and Levi, T. (2018). Projecting the future of an alpine ungulate under climate change scenarios. Glob. Change Biol. 24, 1136-1149. doi: $10.1111 /$ gcb.13919

Wittemyer, G., Northrup, J. M., Blanc, J., Douglas-Hamilton, I., Omondi, P., and Burnham, K. P. (2014). Illegal killing for ivory drives global decline in African elephants. Proc. Natl. Acad. Sci. U.S.A. 111, 13117-13121. doi: 10.1073/pnas. 1403984111

Wolf, C., and Ripple, W. J. (2017). Range contractions of the world's large carnivores. R. Soc. Open Sci. 4:170052. doi: 10.1098/rsos.170052

Woodroffe, R., and Ginsberg, J. R. (2005). "King of the beast: evidence for guild redundancy among large mammalian carnivores," in Large Carnivores and the Conservation of Biodiversity, eds J. Ray, K. H. Redford, R. Steneck, and J. Berger, (Washington, DC: Island Press), 154-176.

World Tourism Organization, (2014). Towards Measuring the Economic Value of Wildlife Watching Tourism in Africa - Briefing Paper. Madrid: United Nations World Tourism Organization.

Xu, J., Grumbine, R. E., Shrestha, A., Eriksson, M., Yang, X., Wang, Y. U. N., et al. (2009). The melting Himalayas: cascading effects of climate change on water, biodiversity, and livelihoods. Cons. Biol. 23, 520-530. doi: 10.1111/j.1523-1739. 2009.01237.x

Yeakel, J. D., and Dunne, J. A. (2015). Modern lessons from ancient food webs. Am. Sci. 103, 188-195.

Yeakel, J. D., Pires, M. M., Rudolf, L., Dominy, N. J., Koch, P. L., Guimarães, P. R., et al. (2014). Collapse of an ecological network in Ancient Egypt. Proc. Natl. Acad. Sci. U.S.A. 111, 14472-14477. doi: 10.1073/pnas.1408471111

Young, J. A., and Sparks, B. A. (2002). Cattle in the Cold Desert. Reno: University of Nevada Press.

Young, J. K., Olson, K. A., Reading, R. P., Amgalanbaatar, S., and Berger, J. (2011). Is wildlife going to the dogs? Impacts of feral and free-roaming dogs on wildlife populations. BioScience 61, 125-132. doi: 10.1525/bio.2011.61.2.7

Zager, P., and Beecham, J. (2006). The role of American black bears and brown bears as predators on ungulates in North America. Ursus 17, 95-109.

Conflict of Interest: The authors declare that the research was conducted in the absence of any commercial or financial relationships that could be construed as a potential conflict of interest.

Copyright (c) 2020 Berger, Wangchuk, Briceño, Vila and Lambert. This is an openaccess article distributed under the terms of the Creative Commons Attribution License (CC BY). The use, distribution or reproduction in other forums is permitted, provided the original author(s) and the copyright owner(s) are credited and that the original publication in this journal is cited, in accordance with accepted academic practice. No use, distribution or reproduction is permitted which does not comply with these terms. 